University of Massachusetts Amherst

ScholarWorks@UMass Amherst

Masters Theses 1911 - February 2014

1940

\title{
A history of Jewish education in Buffalo.
}

Aaron Klein

University of Massachusetts Amherst

Follow this and additional works at: https://scholarworks.umass.edu/theses

Klein, Aaron, "A history of Jewish education in Buffalo." (1940). Masters Theses 1911 - February 2014. 2682.

Retrieved from https://scholarworks.umass.edu/theses/2682

This thesis is brought to you for free and open access by ScholarWorks@UMass Amherst. It has been accepted for inclusion in Masters Theses 1911 - February 2014 by an authorized administrator of ScholarWorks@UMass Amherst. For more information, please contact scholarworks@library.umass.edu. 


\section{FIVE COLLEGE DEPOSITORY}

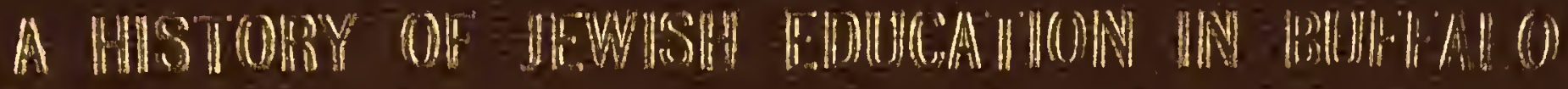

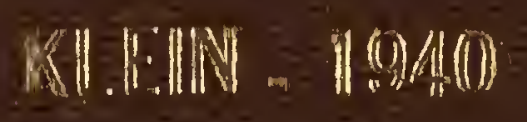


A HISTORY OF JEWISH EDUCATION IN BUFTALO

AARON KIEIN

THESIS SUBNITMED FOR THE DEGREE OF MASTER OF SCIENCE

MASSACHUSETTS STATE COLIEGE 拳 AMHERST, MASSACHUSETTS JUNE 1940 
FORIWORD TO A HISTORY OF JHNISH EDUCATION IN BUFFALO This history is based on primary sources wherever possible, the writer having been fortunate in securing access to the available records of the congregations and schools of the Jewish community of Buffalo. Where such sources were not available, the writer obtained information from periodicals, newspapers, and men and women connected with the various schools, often from their inception.

In point of time the period covered begins with 1847 and ends with the present year.

The story aims to show the beginnings, aims and the development of the various schools, the general problems which beset Jewish education in Buffalo, and the various trends and tendencies which are discernible. The American and Jewish backgrounds and their interrelations are also taken into account.

While each Jewish communty, in the various cities of this country, has its own problems and peculiarities in relation to Jewlsh eđucation, there are sufficient elements in common for Buffalo to serve as a type city, at least, for those cities which approximate it, in the size of their Jewish and general populations. 
A HISTORY OF JEWISH EDUCATION IN BUFFAIO

CHAPTER OINE:

The historical, social and ldeological bases of Jewish education in America

Types of educational systems

CHAPTER TWO:

American democracy and Jewish education

Cultural pluralism

The social philosopher's viewpoint

The educationalist's viewpoint

Jewish education in America defined

CHAPTER THREE:

The city of Buffalo

The Jewish community

The Jewish schools

CHAPTER FOUR:

The beginnings of Jewish education in Buffalo (1848-1900)

Four phases in the development of Jemish education in Buffalo

Early Congregational effort

Private teachers

The "cheder" (private school)

CHAPTER FIVE:

Twentieth Century Developments

The rise of the communal school 
Congregational schools, old and new

Yiddishist efforts

CHAPTETR SIX:

The era of the Bureau of Jewish Education

Its aims, efforts and achievements

CHAPTER SEVEN:

Trends and tendencies as revealed by this study

Buffalo - a typical city 


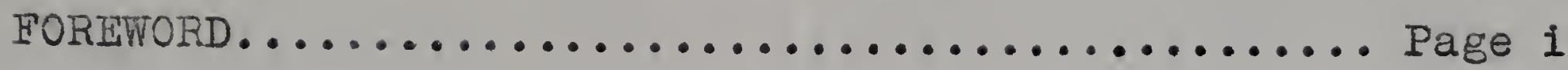

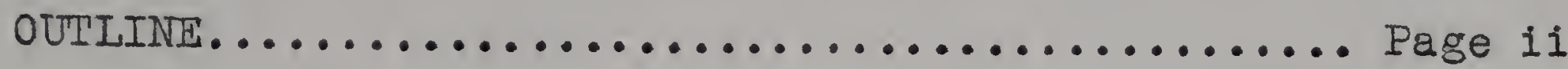

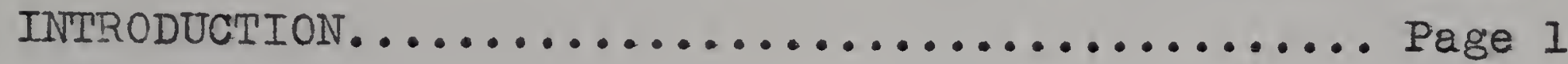

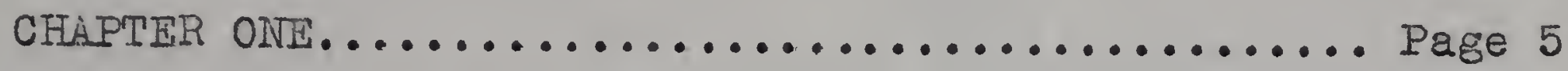

THE BASIS OF JEWISH EDUCATION IN ANITRICA

The historical basis

The social and ideolagical bases

Negative Jews

Positive (Affirmative) Jews

Religionists

Nationalists

Economic Theories

Reconstructionism

Types of educational systems

Notes.

CHAPTER TWO.

Page 28

ANERICAIN DEMOCRACY AND JEVISH EDUCATION

The ideological basis

The social philosopher's viewpoint

The educationalist $\mathrm{s}$ viewpoint

Jewish education in relation to Americanism

Jewish education in America defined

Notes

CHAPTER THREE........................... Page 39

BUFTAIO: THE CITY AIND ITS JEWISH CONMUNITY

The factors to be considered

Location

The ethnological factor

The economic factor

Immigration

The factor of typlcality

Americanization

The Jews of Buffalo

The Jewish schools

Notes

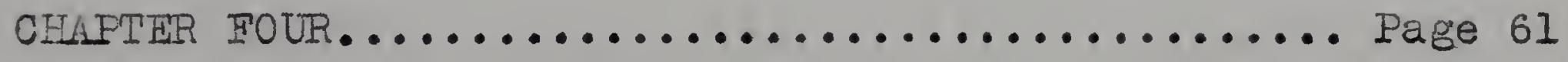

THE BEGINNINGS OF JEWISH EDUCATION IN BLFFAIO: 1848-1900 Four phases of Jewish education in Buffalo 
Temple Beth El

Temple Beth Zion

Private teachers

The "cheder" (private school)

Notes

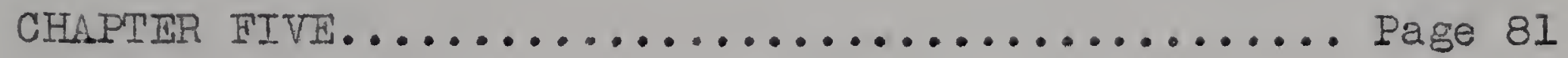

TWENTIETH CENTURY DEVELOPMEINTS: TEE RISE OH THE COMHOHAL

SCHOOI

The Jewish Community Religious School

The Buffalo Hebrew School (TaImud Torah)

The Sunday school of the Buffalo Hebrew School

Congregational schools: new and old

Congre gation Ahavat Achim (Brotherly Love)

Temple Beth El

Temple Beth Zion

Temple Beth David

Temple Emanu El

The efforts of the Yidaishists

The Buffalo Volkschule

Notes

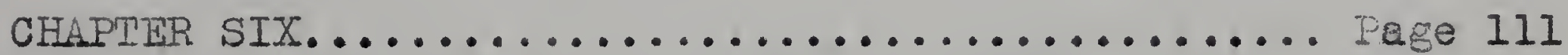

THE ERA OF THE BUREAU OF JEWISH EDUCATION

Herman Wile and his associates

The Survey of Jewish Education by Louis Hurwich

The materialization of the Bureau

The Bureau and the Buffalo Hebrew School

The scope of the Bureau's functions

Attempts at reorganization

Expansion of activities

The Workmen's Circle School

The High schools of the Bureau

The Bureau and the Jewish Community Religious School

The Bureau's accomplishments - an estimate

Notes

CHAPTER SETEN.

TRENDS AND TENDENCIES

Collateral agencies

Recapitulation

Handicaps

Progress

Americanizing influences

Trends and tendencies summarized 
Buffalo a typical city Notes

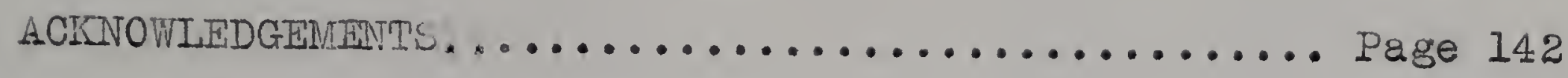

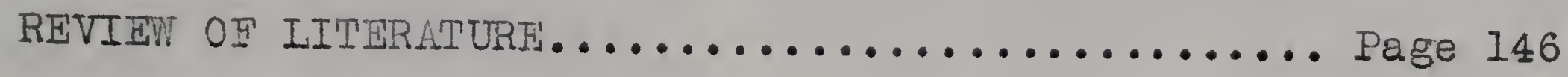

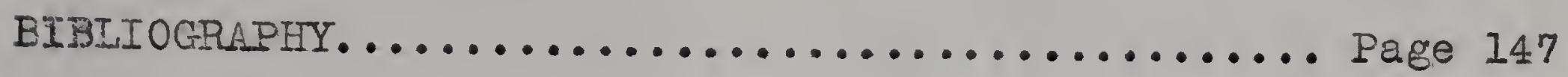


The perennial problem of the Jew is - survival. It is no doubt true that all nations are confronted with this selfsame problem. But it is visited upon the Jew in a somewhat more complex form in that the Jewish people are - and have been for many centuries - a dispersed people. Dwelling in many countries simultaneously, they must cope with the problem of adjustment to their separate environments and at the same time contrive to retain their identity as a Jewish group.

The extent to which they have survived and the survival techniques which they have evolved have varied with time and place. In the present era those countries in which the political and social patterns of life are democratic tend to be more congenial to Jewish survival than those countries in which a totalitarian philosophy predominates. And there is some ground for the view that this is not merely attributable to chance but rather to the inherent democratic tendencies of the Jewish people which found expression in the 01d Testament and Talmudic literature - the mainsprings of Jewish life. (1)

One thing, however, stands out quite clearly: no matter what the nature of the program for survival, at any time and in any place, whether hit upon fortuitously or arrived at deliberately, it has always included provision for some system of Jewish education. "In Bible days the Israelites were commanded to teach the Torah to the young and to meditate 
in it day and night..... Among a list of commandments which a Jew should keep, given in the Mishnah and included in the daily prayer book, are honoring father and mother, doing acts of charity, and making peace between people, but 'the study of the Torah outweighs all of these."

This emphasis upon education indicated a love of learning "per se", but it took on added significance particularly after the destruction of the Second Temple. "Jewish education which till then had been a means of preparing the Jewish child for normal life in Palestine became the sole means of maintaining Jewish unity in the Diaspora." The devotion which other peoples give to their homeland, the Jews, rendered homeless by circumstance, gave to the study of Jewish culture.

From the first, when Jews began to arrive in America, they gave their attention to supplying the educational needs of their group. Naturally they brought over with them from the old world not only their traditional conceptions of the substance of Jewish education, but also the methods of instruction to which they had become accustomed. But in course of time, the interplay of environmental influence tended ta modify these methods and to give a definite American imprint to them.

At the same time the Jewish group itself has been undergodng constantly a process of reorientation to the American way of life, an adjustment which has been complicated by the changes and diversifications which have taken place within the Jewish group. The ensuing changes and modifications have 
naturally enough made themselves felt in the sphere of Jewish education also. And in view of the importance which Jews attach to the matter, they have given it deliberate and serious consideration. The ever mounting number of volumes and studies devoted to Jewish education testify to the attention which the subject commands.

However, to visualize this process more clearly, to bring the picture into sharper focus, it will be well to study the evolution of Jewish education in a single community. The writer believes that the information yielded by such a study and the conclusions which may be drawn from it will be of value in an effort to understand similar efforts of the Jewish group elsewhere in the United States.

The city chosen as the background of this study is Buffalo. The motives behind this choice were twofold: (1) The essential character of Buffalo, whose geographic location, history and population unite to make it a focal American city. (5) There is therefore the likelihood that tendencies discernible in that area will be present in most other American cities. (2) The accident of residence; since the writer happens to live in Buffalo, the material for study lies within his reach.

The method to be followed here envisages an analysis of the bases of Jewish education in America; a brief consideration of the city of Buffalo and its Jewish community; a history of the development of Jewish education in Buffalo; and a summary of present trends and tendencies as revealed by this study. 


\section{NOTES}

1. Witt, Rabbi Louis: Judaism and Democracy, Jewish Tracts No. 11, Union of American Hebrew Congregations, Cincinnati, Ohio. Also Berkson, Isaac B.: Theories of Americanization, New York, 1920, pp. 19-2l; and Gamoran, Emanuel: Changing Conceptions in Jewish Education in two books, N. Y., 1924. "The anthropocentric conception of the universe emphasized by the Jewish religion is quite in harmony with the kuman aims of democracy." Book 2, p. 89.

2. The Mishnah is the body of laws which amplified those found in the Torah, and which, first transmitted orally, were later compiled by Rabbi Judah Hanasi toward the end of the second century.

3. Lotz, Philip H., ed. and Crawford, L. H., co-ed.:

Studies in Religious Education, Nashville, Tenn., 1931. From Chap. XXII "Jewish Education in the United States", by Emanuel Gamoran, p. 492 .

4. Lotz and Crawford, p. 494.

5. In viewing Buffalo as possessing traits typical of an American city I was guided largely by the criteria laid down in Midaletown, by R. S. and H. M. Lynd, N. Y., 1929, pp. 7-8. 
THE BASIS OF JEWISH EDUCATION IN ANERICA

There are today in the United States some four and onehalf million Jews. (i) United States in the genuine hospitality it has extended to the immigrant Jew in the past, and the inequivocal manner in which it has granted him political and civil equality throughout its history. The Jew in turn has sought to adjust himself to American life. But the question which has exercised the minds of Jewish leaders is how ta make this adjustment without surrendering Jewish group identity. "Various programs and solutions have been advanced.... [But] the problem basic to all programs of Jewish adjustment in the United States is that of Jewish survival."

What renders the problem more complicated is the fact that the Jewish population does not constitute a unified and harmonious group. The Jews are divided and differentiated as to antecedents, religious viewpoint, national outlook, social philosophy and the like. If there is any unanimity of opinion at all it consists in this, that no matter what their differences and programs, each group (except, as we shall see later, out and out assimilationists! usually envisages some system of Jewish education as a necessary complement of its program.

This matter of Jewish education is of significance not only to Jewish, but to American educators as well. "Whatever 
affects the education of American children - whether directly through the American public schools or indirectly through voluntary school systems - is of interest to the student of American education." of the Jew in terms of his American milieu; the extent to which he preserves his cultural and religious heritage, his folk-ways and social or ganizations; - in other words the means by which Jews "educate their children so as to make them heirs of their social heritage, and at the same time, insure their full adjustment as American citizens," are matters "of significance to the future of America and American citizens." (4)

To understand the educational efforts of the Jewish group anywhere in this country it is of advantage to be familiar, at least in outline, with the origins of Jevish life in the United States, and the various programs which have been advanced to solve the problem of Jewish survival here. Naturally our analysis will, by its very brevity, be unable to embrace in full detail the cormplexity of Jewish life. Moreover, it must not be assumed that Jews consciously fall into specific, clear-cut groups; they rather tend to drift Ietting necessity and circumstance determine their alignments. Besides all groups have elements in common so that there is considerable over-lapping. But with due alIowance for these limiting factors, a description of the Jewish groups will help to appreciate more properly their educational endeavors. 
The Historical Basis

Since Jewish education in this country has largely been determined by the habits, customs and outlooks which immigrant Jews brought with them from abroad, it is in point to inquire into their antecedents. Jewish history in the United States is usually divided into three periods, based upon socalled waves of immigration. Each wave had its source in a particular European area, and the immigrants from each were characterized by certain physical and social traits reflecting their respective European background. The first wave is that of the Spanish-Portugese Jews, 1654-1848; the second that of the German Jews, 1848-1881; and the third that of the East-European Jews from 1881 to the present day.

1. As the primary concern of this study is to be the city of Buffalo, we may dismiss the first wave with but a passing mention, inasmuch as no spanish-Portugese Jews ever settled therein. (6) comparatively few in number and usually held themselves aloof from the mailn stream of Jewish life, their influence is thus (7) of small weight.

2. German Jews began to arrive in this country even before the Revolutionary War. But they came as individuals and their numbers increased slowly. However, as a result of the revolutionary disorders in Germany in 1848, they began to emigrate en masse. "The first comers were favored with little of worldly goods; until they learned the strange language, 
they eked out a living by pedaling and rose but slowly to a competence. Only those that came after 1848 counted a number of better situated families, and there were many possessed of culture." $(8)$ The greater part of them were "strictly orthodox, loyal to the teachings of their ancestral religion and staunch in the observance of its practices. Their educational standards were simple (and traditional), like their conditions of life."

There were, however, some who "brought with them (from Germany) a new cultural ideal, that of the eman(10) cipated Occidental Jew, Judaism, that of Reform, (II) and a new interpretation of the Jews to their new environment. In America the new. 1deals spread rapidly. Reform Judaism was widely accepted. Now, practically every one of the important German Jewish congregations in this country follows the reform ritual."

one of the outstanding contributions made by the German Jews here was the development of special philanthropic institutions to take care of their dependents and their needy. This had hitherto been a traditional function of the symagogre. (13)

3. The third and largest wave of Jewish immigration to this country was that which originated in the lands of Eastern Europe. The ma in stream came from Czarist Russia, but considerable numbers also arrived from Galicia, Roumania and Hungary. Although there had been East-European Jews in America even in pre-Revolutionary days (probably the most famous example is Haym Solomon, who aided the 
Revolutionary cause with large sums of money, and who was

a Polish Jew), the full stream of immigration from those areas did not begin till 1881. The immediate occasion which led Jews in hundreds of thousands to uproot their homes and come here was the pogroms, the mass brutalities to which the Jews of Russia were subjected.

of the four and one-half million Jews in this country today over eighty per cent are directly of East-European origin or children of parents of such origin. This group is thus the strongest numerically speaking. "But more important than [its] numerical strength [is its] importance as a new force in the development of Jewish life in America and the possibilities that [it] offer[s] for the enrichment of American life. This group is very complex, containing within itself many smaller groups." (15)

In his study of Jewish Education in New York City, Dr. Dushkin indicates four types of outstanding interest:

(1) The immigrant orthodox type, "minutely observant of the great mass of rabbinic tradition.... well versed in the literature of the Talmud and the (legal) codes," preserving "with as little deviation as possible in the new land of his adoption" the customs and the likes which he has brought with him from Europe;

(2) The materially "all-right" type, who having achieved economic well-being tends "to live his Jewish life on the 
basis of momentum only, and not to worry greatly over the many problems which confront Jewish life in America.... He is not antagonistic to Jewish activity or to Jewish education, but is, rather, indifferent to these efforts, and will support them, if properly appealed to."

(3) The nationalist Jew, "who is the product of two historic movements. The Haskallah (Enlightenment) movement in Russia during the middle of the last century, caused many Jewish students to forsake the Talmudical halls of learning and seek the wider culture of the western world.... Young men began to devote their energies to the creation of a new literature in Hebrew, expressive of the facts of modern life and of the new orientation of the Jews in the modern worla.... With the Haskallah movement another force combined in creating the nationalist Jew. This force was Zionism. Modern Zionism originated in Russia as a 'Love of Palestine' movement, and spread throughout the world under the leadership of Dr. Theodore Herzl, the founder of the Zionist world organization. It is simply a modern formulation of the age-long yearning of the Jew for Zion. It looks to the establishment of 'a publicly secured,. legally assured homeland for the Jews in Palestine," and to the fostering of Jewish consciousness throughout the world." These two movements, Haskallah and Zionism, are expressive of the Jewish interests of the nationalist Eastern European Jew. He makes up the rank and flle of Zionists in this coun- 
try and he can be found in every movement which makes for the organization and development of American Jewish life."

(4) The radical type, "the creation of the intense revolutionary efforts in Russia, which finally led to the great Russian Revolution. His is a loud cry for social justice.... He swells the ranks of the radical socialist and labor movements in this country. While he throws off the religious elements of his Jewish life, and in many cases also the national phases, he nevertheless ardently preserves his. Jewish affiliation in intensely socialized forms: special Jewlsh organlzations, Jewish labor unions, Jewish newspapers, Jewish schools, etc. He has converted the Jewish intellectual ideal into that of .... one who frees himself from the sanctions of the past, and attempts to live by 'cold' intellect alone."

\section{The Social and Ideological Bases}

Having considered its European origin, we may then proceed to an analysis of the social and ideological forces which divide the Jewish group. It must be borne in mind that it is difficult to make any fine distinctions, because all the various segments of the group tend to merge into each other; and most Jews, "like other humen beings, do not have highly conscious motives in their being and thinking.... In the majority of cases, the American

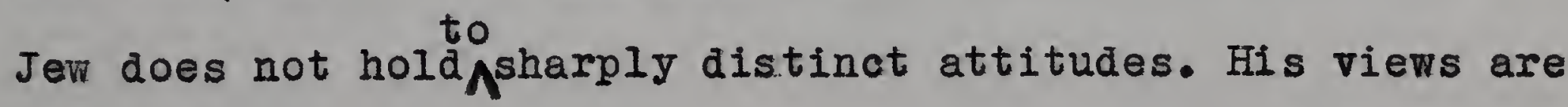


eclectic, and partake of the characteristics of several classes." Nevertheless, two types can be discerned: the positive and the negative Jew.

\section{Negative Jews}

It will be convenient to consider the negative group first. By negative Jews we have in mind such Jews who belong to the Jewish group merely by accident of birth. Their most outstanding trait as Jews is their desire to appear - other than Jewish; in short, to completely assimilate with and become submerged by their environment. A good statement of the assimilationist position is to be found in Dr. Karpe's Jewish Community Organization in the United States. "In this category are grouped those who have no interest in Jewish survival, and who hold, on the contrary, that the Jews are doomed to extinction through the process of assimilation which is constantly going on. This process, they believe, should be encouraged, and cannot and should not be stopped. Some of the moderates among them may belleve that it should be retarded. But even they view assimilation as desirable and inevitable." Economically and politically this group represents the two extremes of Jewish life, being "either extremely conservative or reactionary if they are wealthy, or.... among the most radical Marxists if they are. workers." (18) 
Jews in this group scout all efforts at preservation of all forms of Jewish communal life. They are, therefore, Indifferent - when not overtly and actively opposed - to Jewish education.

\section{Positive (Affirmative) Jews}

For the sake of simplicity it will be convenlent to divide the Jews who fall into this category into three types: Religionists, Nationalists and Economic Theorists. As already suggested, these groupings are not always mutually exclusive. Nevertheless each by itself represents a definite point of view as regards Jewish survival.

\section{Religionists}

Jews are divided in their religious outlook and practice into three groups: Orthodox, Conservative and Reform. To attempt an exhaustive analysis of the position of each division is here beside the point. The description here given aims to supply only those details which help to clarify the aspect under consideration - Jewish education.

(1) Oxthodoxy: The ensuing statements summarize the Orthodox position. "To the Orthodox, Judaism is a supernaturally revealed religion. The Bible is to them the revealed Book of God and is an all-embracing guide in solving all of life's problems. To the orthodox Jew, everything which is outside the province and purview of his "religious' life is of secondary importance." (19) 
More specifically, "the characteristic attitude of the orthodox is the w1sh to preserve unaltered those religious institutions and customs which have been codified into Jewish law, particularly into the code of Rabbinic laws known as the 'Shulchan Aruch' ('The Table Set'). This legal code deals with every aspect of life in great detail.... Its purpose is to bring to the ordinary Jew, in an available form, the vast rabbinic legal tradition, which regulates every phase of human life. Prayers, meals, business transactions, marriage, birth, death, recreation, work, all possible human relationships are regulated in accordance with the development of Jewish tradition, which has its origin in the Bible, and continues through the Talmud to the postTalmudic rabbis."

The purpose of educating a Jew in the observance of all minutiae of ritual and law is to produce a God-fearing man, who by very possession of this virtue, becomes a good human being, whose conduct is a living expression of the ethical ideals of the prophets. (21)

(2) Reform: The Reform Jews are in a sense diametrically opposed to the Orthodox. The Jewish Reform movement began in Germany toward the end of the eighteenth century; reached its most vigorous stage there in the early nineteenth century, and, crossing the Atlantic, reached the peak of its development here between 1850 and 1900. The official attitude of the American Reform movement was for mulated at a conference of Reform Rabbis held in Pittsburgh in 1886. 
"The Reform movement abrogated practically all of the laws which arose and were codified after the Talmud, as well as many of the Talmudic regulations, and even some of the biblical injunctions. Its leaders called themselves followers of Prophetic Judaism, meaning thereby that they wished to make the Prophets, rather than the Pentateuch, the guides and authorities for their Jewish social life. Their aim was to interpret the values of Judaism for the modern environment in which the Jews lived, following their emancipation in the countries of Western Europe. Their more concrete reforms were in making the Jewish synagogue ritual more simple and more aesthetic." (22)

More radical was the Reform Jews' repudiation of Jewish nationhood and the adoption of the view that the Jews are only a unique religious body. Since the World War individual Reform Jews or even whole communities have modified their stand both as to observance and outlook. Thus today "there are many Reformists who are ardent Zionists." (23) But the official attitude of this group has never been supplanted; and thus the Platform drawn up at the Pittsburgh conference of 1886 has remained the official expression of, the Reform Jews' stand.

In view of its special and almost exclusive emphasis that Judaism is a religion, Reform Jewry conceives of Jewish education as religious education. "Because the teaching of religion is excluded from the public schools, it is necessary to provide supplementary schools for the teaching of religion. It is the sunday school which has become the standard type of Reform School. $\left(^{24)}\right.$ 
(3) Conservative: The Conservative Jew and the attitude he represents tend to escape precise definition. Conservative Judaism originated in the nineteenth century when Reform Judaism and its doctrines began to play havoc with traditional Judaism, and the break-up of the ghetto threw the Jew, almost unprepared, upon a world that overwhelmed him. Those Jews who sensed the resultant threat to Jewish existence and who, while aware that they must reckon with the new challenges, yet wanted at the same time to preserve as much as they could of Jewish life, launched what became known as Conservative Judaism. (25)

"It represents today the evolutionary attitude in Judaism. It refuses to break with the past, but insted, gradualIy discaràs those customs and laws which are felt to be no longer tenable or necessary. It is a functional conception of Judaism.... It refuses to make the distinction between the spiritual, or religious phases of Jewish life, and in the corporate or national aspects. It claims that Jewish spirituality has meaning only with reference to Jewish group life.... It does not consider Jewish religious life as having ceased in its development." (26) As Jewish life finds the greatest scope for its expression in the synagogue it is essential that every Jew be a member of some specific congregation. For its Jewish education each congregation usually conducts a supplementary religious school. 
The theoretic aims of Conservative Jewish education are the training of the "Jewish child to particlpate intelligently in the life of the synagogue," and bequeathing to him "a knowledge of the Bible and other Jewish Iiterature." Added aims are the integration of "the Jewish child into the larger Jewish life of his community, his country, and world Jewry; a knowledge of Hebrew as the "historic language of the Jewish people" and as the "living language of Palestine and of the Jewries of other countries today; the implanting of a sense of Jewish responsibility, helpfulness and loyalty, and a love for Palestine as a national Jewish home. A further aim, more general in its scope, is "to make the Jewish child a better man or woman." (27)

\section{Nationalists}

Jewish nationalism is linked with Zionism. Nationalist strivings among Jews are an offspring of pre-war (1914) European nationalism, and of the "treatment accorded the Jews by the different nations. In the countries of Eastern Europe it was the rightlessness of the Jewish people, the segregation and consequent congestion of the Jewish masses, the persecutions and discriminations against the Jews, which gave rise to Zionism. In the countries of Western Europe it was antisemitism which drove the Jews to espouse Zionism."

There are various versions of Jewish nationalism. But the one most current in the United States is the theory of 
Spiritual Zionism. According to its view, the Jew can best hope to survive by a return to Palestine. But as not all the Jews in the world can be absorbed by that country, it follows that there must always be a Diaspora-Jewry. How shall this body preserve its Jewish spirit under conditions of modern living which require that the Jew lead an existence in the midst of non-Jewish cultures and even that he (quite justifiably) participate in the cultural and national life of his non-Jewish environment?

The answer from the Spiritual Zionist standpoint lies in the concept evolved by Ahad Ha-am. (29) thinker, Palestine will serve as a spiritual center from which the fruits of the creative spirit of the Jew will emanate and radiate in all directions, unifying the dispersed Jews and giving ever fresh meaning, stability and vitality to their lives. (30)

In this country the communal Talmud Torah (House for the Study of Torah) comes nearest to expressing educationalIy the aims and outlook of Spiritual zionism.

\section{Economic Theories}

The economic outlook of the Jews is diversified and depends on each individual's position in the economic scale. There are, thus, to be found among Jews proponents of every shade of economic thought. Amongsome Jews whose outlook is that of the working-class, there has emerged a standpoint 
on Jewish existence which can best be described as secularist. In matters of religion members of this group take the view that it is the private concern of the individual. Its organized form is best typified by the Workmen's Circle. which operates supplementary schools, in which the language of instruction is Yiddish. The reason for this is the view that Yiddish is the Ianguage of the Jewish masses. Yiddish literature, Jewish history and the story of the workingclass movement are the subjects of major emphasis.

\section{Reconstructionism}

Reconstructionist Judaism is a late development among Jewish groups, and in view of its recency and special character, it has been detached from the framework of discussion in which the other groups were considered. Its founder and foremost spokesman is Dr. Mordecai H. Kaplan of New York City, and in his Judaism as a Civilization he expounds the Reconstructionist philosophy of Judaism. Indicating the inadequacies of the various religious and secular systems of Jewish Iife, Dr. Kaplan maintains that the key to the solution of the question: In what does Judaism consist? - lies in the word civilization and all the term implies. As a civilization Judaism is neither merely a reIigious nor a mere secular group. "Judaism.... is..... something far more comprehensive than Jewish religion. It includes that nexus of a history, literature, language, social organization, folk-sanctions, standards of conduct, 
social and spiritual ideals, esthetic values, which in their totality form a civilization."

This new approach to Jewish living has, partly through Its inherent appeal, and partly through the influence of its leading exponent, Dr. Kaplan, acquired a large following, not so much among the Jewish laity as among the Jewish clergy, social workers and educators. Amongrabbis it cuts across religious groups, finding adherents for itself among Reform, Conservative and, occasionally, Orthodox rabbis. Through them the point of view is distilled in sermons, club groups and the like to the various congregations; and social workers in community centers give practical application to the outlook through the wide and more inclusive types of program they foster.

The educational implications of Reconstructionism are summarized in the following statement: "The aim of Jewish eduation may be defined thus: to develop in the rising generation a desire and a coppacity, (I) to participate in Jewish life, (2) to understand and appreciate the Hebrew language and literature, (3) to put into practice Jewish patterns of conduct both ethical and religious, (4) to appreciate and adopt Jewish sanctions and aspirations, and (5) to stimulate artistic creativity in the expression of Jewish values...... All these objectives presuppose a type of Jewish life which is completely integrated into a progressive and dynamic American life."

(34) 
This approach, as has been intimated, has in varying degree affected the educational efforts of different Jewish groups. But, with only one exception, (35) as yet established any schools of its own.

\section{Types of Educational Systems}

The foregoing analysis indicates the complex and heterogeneous nature of the Jewish group in America. It has al so suggested the educational outlook of the various groups based upon their particular attitudes. We may summarize now the type of school sponsored by each group.

(1) Jews who view assimilation as desirable naturally subscribe to no Jewish education at all and thus have no schools.

(2) Yeshivah (Iiterally session or a sitting) is the nearest Jewish approach to the parochial school. The strongest advocates of this form of education are the orthodox. Jews. Where the Yeshivah is, for practical reasons out of the question (actually only few such schools exist and only in cities of heavily concentrated Jewish population such as New York and Chicago; Buffalo and cities whose Jewish population is approximately the size of that of Buffalo have no Yeshivah) orthodox Jews seek the solution of their educational problem in the Talmud Torah (see below). The goal of Jewish education in the Yeshivah, as well as the center of its curriculum, is the mastery of the Talmud. 
(3) The Talmud Torah (IIterally, Study of the Law) is a supplementary weekday school, drawing its adherents from Orthodox and Conservative circles. The Talmud Torah is usually a communal school, that is, supported by those in the community at large who favor its existence. "In these schools the Bible, and post-biblical literature, form the center of the curriculum. Jewish history, religion and ethics are important elements in the course of study." (35)

(4) The Congregational 5 chool is a relatively new phenomenon in American Jewish educational circles. It is a supplementary weekday school. In its essentials it follows the pattern laid down by the Talmud Torah. The chief difference is that the maintenance of the school is the responsibility of a specific congregation rather than that of the community at large. Although some orthodox synagogues maintain such schools, they are to be looked for most often in Conservative congregations. A tacit aim of these schools is the fostering of loyalty to the synagogue as the major group expression in Jewish life.

(5) Sunday Schools are stressed chiefly by Reform Jews, although Conservative and (rather rarely) orthodox congregations maintain this type of school as well. Instruction in these schools is limited to sunday mornings, on which day some two hours of study are devoted to Jewish history, ethics and a skeleton of religious observances. In pattern this type of school is familiar to 
Americans. Historically it originated as a result of the example set by the American Sunday School Union, organized in Philadelphia, and throughout its development it has fashioned its curriculum and management on the Protestant model." (37)

(6) Yiddishist Schools: This term loosely describes the type of school advocated by Jewish seculartst-socialist groups. Yiddish is at once the language of instruction, as well as the chief subject of the curriculum. Until recently secularist-socialist Jews were sharply divided among themselves. One group, known as the Arbeiter Ring (Workmen's Circle), was cosmopolitan in outlook. It favored fusion with the non-Jewish proletariat and established its own supplementary weekday schools. Opposed to the Arbeiter Ring was the Jewish National Workers' Alliance of/America. This latter group was also socialistic in its economic viewpoint, but considered itself culturally and nationally a part of the Jewish people, and wanted to preserve its group life. It accordingly opened schools of its own.

Today the Arbeiter Ring has made a rapprochement with. all other national workers' groups and its schools have taken on a national tinge. Thus Jewish holidays are observed and taught - though largely in a secular-nationalist spirit, and not as religious festivals. $(38)$

There are then several types of Jewish schools, each tending to represent the viewpoint of a specific group. However, it is not uncommon for a number of groups to sup- 
port a given type of school, or for one group to lend its aid to several types of school.

The analysis contained in this chapter is general both in scope and in scene. In later chapters dealing with Buffalo, it will be seen that the elements of this analysis apply in almost full extent to that city in particular. 
NOTES

1. Karpf, Maurice J.: Jewish Community Organization in the United States, N. Y., Bloch Pub. Co., 1938, p. I.

2. Karpf, p. 41 .

3. Dushkin, Alexander M.: Jewish Education in New York City,

N. Y., Bureau of Jewish Educetion, 1918, p. I.

4. Dushkin, p. 1 .

5. Restrictive legislation tended to curtail general immigration from 1922 on. Mass immigration by Jews naturally dropped sharply also. But the treatment accorded the Jews in Nazi Germany since 1933 has tended to create once again a minor wave of Jewish immigration to this country; it is, however, still too early to know. whether this latter wave will have any significant effect on the Jewish educational picture. See Karpf, pp. 31-32. 6. "A Study of the Early Jewish Community of Buffalo, 18351880," article by Aaler, Selig in Buffalo Jewish Review, Oct. 14, 1932.

7. But it may not be entirely dismissed in such communities where they are established as a fairly numerous group. 8. Margolis, M. I., and Marx, A.: A History of the Jewish People, Phila., Jewish Pub. Society, 1927, p. 675. 9. Dushkin, pp. 32-33 and footnote 15 .

10. Shortly before the French Revolution (1789) and thenceforth, various Western European governments - England, France, Bavaria, Austria, etc. - began extending civil 
and political rights to Jews. This era is known in Jewish history as the Age of Emancipation.

11. For a discussion of Reform Judaism and its educational implications see below, pp. 14-15.

12. Dushkin, p. 33.

13. Dushkin, p. 33. Many synagogues individually still maintain today various philanthropic undertakings. But the major philanthropic activities are extra-synagogal and usually communal projects.

14. Karpf, p. 6 .

15. Gamoran, Emanuel: Changing Conceptions in Jewish Education in two books, N.Y., 1924, pp. 3 and 4. Also Dushkin, pp. 34-35 and footnotes.

16 Dushkin, pp. 35-37 and footnotes.

17. Dushkin, p. 2 .

18. Karpf, pp. 49-50.

19. Dinin, Samuel: Judaism in a Changing Civilization, N. Y., Teachers College, Columbia Univ., 1933, pp. 6-7.

20. Dushkin, pp $6-7$.

21. Dinin, p. 8 .

22. Dushkin, p. 7 :

23. Dinin, p. 9 .

24. Dinin, p. 12.

25. Dinin, p. 13.

26. Dushkin, p. 8.

27. Dinin, p. 16. 
28. Dinin, p. 18.

29. Outstanding Hebrew essayist and thinker (1857-1927).

30. Dinin, p. 19.

31. Dinin, p. 20 .

32. Dinin, p. 37 .

33. Kaplan, Mordecai M.: Judaism as a Civilization, N. Y., Macmillan, 1934, p. 178.

34. Kaplan, p. 482.

35. The Society for the Advancement of Judaism, N. Y. C., is the only organization having a school activated specifically by Reconstructionist philosophy. Its spiritual leader is Dr. M. M. Kaplan.

36. Dushkin, p. 14 .

37. Dushkin, p. 14 and footnote. Also Lotz, Philip, ed. and Crawford, I. H., co-ed.: Studies in Religious Education, Nashville, Tenn., 1931, chap. XI.

38. Dinin, pp. 24-38. 


\section{CHAPTER TWO}

\section{AMERICAN DEMOCRACY AND JEWISH EDUCATION}

In the endeavor of the Jews to adjust themselves to American life the Jewish schools have played an important role, and their variety merely reflects differences in method of adjustment. All, however, find a basis for their educational efforts predicated in the inherent nature of American democracy. There are various theories of American democracy; but the theory which usually underlies Jewish endeavors towards adjustment is that of some form of cultural pluralism.

\section{The Ideological Basis}

(1) The social philosopher's viewpoint: The Jews are a minority group in America and their participation in American life what time they seek to preserve their identity represents a problem upon whose solution depends the happiness of many human lives. It is naturally a problem not confined to Jews alone. America contains a number of minorities, religious and national, and a solution must be reached whereby all shall contribute to the enrichment of American life, not by self-effacement but by assembling the best elements of each group into a harmonious blend with that which is fundamentally American.

At the close of the previous century the doctrine of Americanization most often voiced was that of the "melting-pot". The view of adherents to this outlook was that 
America was a vast social crucible into which was constantly poured a stream of admixed, foreign elements, national and religious, all of which would in time emerged fused and with a distinct and like American pattern. But "the theory did not work, the minority cultures did not melt, but held aloof from American life, continuing their cultural practices isolated from American life." (1)

A new guiding philosophy, a new approach to American life and the minority question was felt to be needed; Wrote Herbert Croly in 1914: "The conscious bond of a common faith [progressive democratic ideals] makes not for an indiscriminate fusion, but for a genuinely social union, constituted both by individuals and by those smaller social groups which give distinction to so much of individual life. The bond stimulates mutual understanding and is itself strengthened thereby." (2)

A decade later Mary P. Follett phrased the idea rather trenchantly in her book Creative Experience. "We need a technique of human relations based on the preservation of the integrity of the individual. Of late years we have heard too much of the collective life as an aim in itself. But who cares for the 'collective life'? It is usually a mere shibboleth of empty words. What we care about is the productive life, and the first test of the productive power of the collective life is the nourishment of the individual." (3)

Thus the melting-pot has begun to give way and "in 
recent years a new theory of the adjustment of minority groups to major civilizations has been emerging, that of cultural pluralism. This theory.... assumes that no culture contains all favorable elements, but that each group that makes up the total American population has unique values, and that the nation will be richer and finer in its cultural make-up if it, the country, preserves the best that each group has brought. The theory assumes, furthermore, that these minority groups have been so completely conditioned by their heritages that the historic past could not be sacrificed even if they chose to forget their past experiences. Their natures, character, and personalities are built out of a culture different from our own, and the method of effective cultural transmission requires that the fundamentals of their heritage be preserved for generations. The only other option is cultural deterioration, the degeneration of family life, and maladjustments in our social life."

(2). The educationalist's viewpoint: This theory (cultural pluralism), which in somewhat modified forms goes by other names, such as "trans-nationalism" and the "community theory", (6) represents the stand of modern sociological thinkers. On the educational level the concept has received support from some of the leaders in educational-philosophic thought. An adumbration of the idea may perhaps be perceived 
in Nicholas Murray Butler's definition of education as being a "gradual adjustment to the spiritual possessions of the race with a view of realizing one's own potentialities." (Italics ours) Typical of the thinking of John Dewey, from whose writings numerous references coula be cited, is this quotation.: "If democracy has a moral and ideal meaning, it is that social return be demanded from all and that the opportunity for development of distinctive capacities be affordeã all."

For Jews, group life in its more intimate phases means association with other Jews, even as among PolishAmericans group life implies association with other Poles, and so on through the heterogeneous list of groups which, taken together, constitute the American people. There is nothing of the alien spirit in this phenomenon; it is rather the outcome of a natural human tendency, the gregarious instinct carried to its logical conclusion. Education, says Charles A. Beard, "must prepare youth for associational life and activities." ${ }^{(9)}$ In so far as Jewish group life is concerned, Jewish education alone can assume this educational function.

If, as Ross Lee Finney repeatediy maintains, this is "the democratic ideal - that every human being has an inherent right to happiness and self-realization," ${ }^{(10)}$ its achievement must rest on such premises as cultural pluralism implies. The crux of the matter is brought home to 
us in this statement: ".... Real democracy of necessity demands divergence of cultures, nationalities, and religions, and free interplay between ethnic, cultural, and national and religious minority groups. The individualization of society must include the individualization of minority groups, and in socializing the individual, we must socialize him into his own group as well. This does not mean that America must merely tolerate cultural divergences; but that it must promote and encourage them."

Jewish Education in Relation to Americanism

The conclusion at which we must, therefore, arrive is that Jevish education is essential if the American Jew is to make his just contribution to the whole pattern of American life. "Loyalty to America is not developed merely through the negative virtue of disloyalty to one's ethnic group." (12) Indeed, the Jew cannot, even if he would, discard overnight his centuries-old traditions, and the habits of life which those traditions and the common experiences of his people have conferred upon him. If his personality is to be unthwarted and enriching to American society, he must, as an individual and through his group, continue to live in terms - modified, to be sure, by the influences of the total American environment - of his past social and cultural heritage. It is only thus that he can be an individual of dignity and proper human worth. And if he is to be on familiar terms with his past the most effec- 
tive device he can employ is - education.

It is not, however, merely in the enriching and integrating of personality that Jewish education acquires significance. In the field of character training leading to effective citizenship it has a further contribution to make. For Jewish education lays stress on ideals and loyalties per se. "The Jewish teacher has nothing to offer the Jewish child in terms of material or social advancement. He must stress values of Iife other than tangible ones. He must make the conscious adherence to loyalty and to auty the central attitudes in his teaching. His task is to instruct American Jewish children to be true to their Jewish obligations and responsibilities because they are obligations (13)

and responsibilities." The extension of a sense of loyalty from the ethnic group to America itself is implicit in all Jewish education.

But Jewish education has other and more immediately germane purposes to achieve - ends which only Jewish education can attain. American education is largely non-religious. "The public schools [perforce] must be public. They dare not admit those personal preferences that are made the differentiating principles of parties and sects." But although Jewish education is more than mere religious education in the denominational sense, it teaches - except in schools guided by a conception of Jewish life as being secular only - aspects of religion which are peculiarly 
Jewish and can only be taught competently in a Jewish school. It thus seeks to supplement public education with such knowledge and experience which is generally regarded as vital to the complete education of the individual, and yet, in the framework of American education, can only be transmitted through supplementary schools. For, as Kilpatrick has aptly put it, albeit in a somewhat other context, "mere school (public) education cannot possibly suffice for the whole of life." (15)

In sum then, it may well be said that Jewish schools are an expression - one of many, to be sure - of American cultural democracy at work. For the first Jews, like other groups, were attracted to America not merely for economic betterment, but to be able to secure that integrity for their persons which was denled them in European lands. They regarded their coming here as the fruition of a dream, perhaps that very dream of which James Truslow Adams speaks so glowingly in the closing pages of his Epic of America. "The American dream" - the passage deserves quoting in fulI for sheer appositeness - "that has Iured tens of millions of all nations to our shores in the past century has not been a dream of merely material plenty, though that has doubtless counted heavily. It has been much more than thet. It has been a dream of being able to grow to fullest development as man and woman, unhampered by the barriers which had slowly been erected in older civilizations, unrepressed 
by social orders which had developed for the benefit of classes rather than for the simple human being of any and every class. And that dream has been realized more fully in actual life here than anywhere else, though very imperfectly even among ourselves."

Jewish Education in America Defined

From the analysis of American Jewish Iife presented in the previous chapter, and from the aims and aspirations of Jewish education in terms of the American cultural democratic ideals here described, it will be seen that no simple and single definition of Jewish education will suffice, to make clear its nature and scope. It is not mere religious education but rather education into a unique and many-sided civilization. Its various aspects have been well defined by $\mathrm{Dr}$. Dushkin in this wise:

"(1) Psychologically, Jewish education is the process of enriching the personality of American Jewish children, by transmitting to them the cultural heritage of the Jews, and by training them to share in the experiences of the Jewish people, both past and present.

"(2) Sociologieally, Jewish education has two meanings:

(a) It is the transmission of group consciousness by Jewish fathers to their chilaren, so as to preserve Jewish life.

(b) It is the mental and social adjustment of the American Jewish children, so that by preserving the values 
of their people, they may be able to live the completest, and, at the same time, the most cooperative lives.

"(3) Religiously, Jewish education may be defined as the training of Jewish children to understand and obey the will of God as it has expressed itself in the history, Iiterature and laws of their people."

\section{(17)}

In the following chapters, when we turn our attention to the Jewish community of Buffalo proper, we shall consider it specifically in the light of its educational undertakings viewed in relation to the previous analyses. 
NOTES

1. Brown, Francis J. and Roucek, Joseph Slabey, editors:

Our Racial and National Minorities, Prentice-Hall Inc., N. Y., 1937, p. 761 .

2. Croly, Herbert: Progressive Democracy, Macmillan, N. Y., $1914, \mathrm{p} .192$.

3. Follett, Mary P.: Creative Experience, Longmans Green,

N. Y., 1924, p. xil1.

4. Brown and Roucek, p. 762.

5. See Bourne, Randolphe: The History of a Literary Radical,

B. W. Huebsch Inc., N. Y., 1920, pp. 266-299.

6. See Berkson, Isaac B.: Theories of Americanization, Bureau of Publications, Teachers College, Columbia Universit $y, N_{\bullet} Y_{\bullet}, 1920$.

7. Butler, Nicholas Wurray: The Meaning of Education, Scribner, N. Y., 1915, (revised and enlarged edition) p. 25.

8. Dewey, John: Democracy and Education, Macmillan, N. Y., 1816, p. 142 .

9. Beard, Charles Austin: The Unique Function of Education

in American Democracy, Educational Policies Commission, National Education Assodation of the United States, Washington, D. C., 1937, p. 93.

10. Finney, Ross Lee: A Sociological Philosophy of Education, Macmilian, N. Y., 1929, p. 89.

11. Dinin, Samuel: Judaism in a Changing Civilization, Bureau of Publications, Teachers College, Columbia University, N. Y., p. 80 . 
12. Gamoran, Emanuel: Changing Conceptions in Jewish Education, in two books, Macmillan, N. Y., 1925, p. 44, book two.

13. Dushkin, Alexander M.: Jewish Education in New York City, The Bureau of Jewish Education, N. Y., 1918, p. 20 .

14. The Essential Place of Religion in Education, Monograph published by National Education Association, Ann Arbor, Michigan, 1916, p. 8. (Essay by C. E. Rugh)

15. Kilpatrick, William Heard: Education and the Social Crisis, Liveright Inc., N. Y., 1932, p. 50.

16. Adams, James Truslow: The Epic of America, Iittle Brown and Co., Boston, 1931, p. 405.

17. Dushkin, pp. 26-27. 
CHAPTER THREE

BUFFALO: THE CITY AND ITS JEWISH COMMUNTY

Although the city of Buffalo lies within the geographic limits of the state of New York, it is not, essentially, an eastern city. Indeed in many respects it "is much more like the cities of Missouri, and Ohio and Michigan than Rochester." Such is the recently expressed opinion of Carl Carmer, student of American folk-lore. "Buffalo," he goes on to say, "is a broad, gusty, powerful city. OnIy in a few old ways is it characteristic of the country that lies east of it. This sprawling, bustling town is no longer upstate. Buffalo is the beginning of the Midale West." (Italics our own)

The Factors to Be Considered

(1) Location: Even in an earlier day people were already aware of certain special qualities which rendered Buffalo one of the cities of peculiar interest in America. What set it apart from the outset was its location. Situated in a "strategic position at the easterly end of Lake Erie" (2) it was destined - particularly after the building of the Irie Canal - to be the focal point through which would pass all manner of traffic, commercial and human. New Englanders on their way westward and Westerners on their way to New York or New England would, as a matter of course, usually find it necessary and convenient to go by way of Buffalo. And it was but natural that from time to 
time travelers in either direction should decide to tarry awhile and eventually, seeing its industrial and commercial possibilities, make Buffalo their permanent home. Thus from the first Buffalo became the meeting ground of early American cultures - New York/New England and the West.

That Buffalo has been conscious of its well-favored position there can be no doubt. "Essentially," wrote F. H. Severance, secretary of the Bufralo Historical society, "Buffalo is the child of the Great Lakes.... The group of Middle States was largely settled by people who passed through Buffalo as through a door, seeking new opportu-.. nities." And significantly enough, the Buffalo Year Book of 1920 bears the title: "Buffalo America's Gateway to and from the Great North West." Again, Severance, writing in the civic section of this selfsame yearbook, gives the matter further stress. "The story of Buffalo is the story of a typlcal American town that owes its origin to the pioneer movement and to the development of transportation at the beginning of the nineteenth century. It owes its growth in the last half century chiefly to transportation and to industrial development." (5) be overlooked, too, that in becoming an industrial center, Buffalo has been aided to a large extent by its proximity to Niagara Falls and the relatively cheap electric power these supply.

(2) The Ethnological Factor: This movement of men and goods to and fro has carried in its train a variety of influences, social and cultural, as well as economic. This 
phenomenon has been aptly described by Frederick J. Shepard. "Buffalo is the eastermost of America's western cities. Lying upon the eastern edge of the vast plain that stretches from the Appalachians to the Rocky Mountains, she is a western city in her physical aspects, in her rapid growth, in the general type of her industries, and in a certain frankness and ease of social intercourse; while her distance of less than nine hours by rail from New York, the conservatism of her business methods, the New England origin or ancestry of most of her people who are not of foreign extraction, and her aspirations in letters and art equally entitle her to a place among eastern towns. Recognizing this intermediate position, geographically and socially, Buffalonians boast that they enjoy the advantages of both Boston and Chicago, and the disadvantages of neither." (6)

(3) The Economic Factor: A cursory perusal of the latest issue of the Buffalo city directory will suffice to indicate the variety in the pattern of her economic life. It is a city of commerce and diversified manufacture. It is also a center for all types of transportation - land, sea and air - as well as for grain, live-stock and the iron industry. (7)

(4) Immigration: Because of the rapidity of the growth of its industries, Buffalo found its native supply of labor inadequate. It had to, rely on immigrants to fill its needs. 
One result of this situation is that "in the character of her population Buffalo has always been cosmopolitan. As early as 1821 immigrants from Germany began locating here. It was not, however, until 1848 and years immediately following that the great influx of German-born people set in.... In 1880 it was estimated that the population of Buffalo was one-half German-born, or descendants of German-born parents. About that time, too, began the Polish migration. This has continued intermittently to very recent years, so that Buffalo's PoIish colony today [1920] is a very important part of her population, estimated at 135,000 . The city is sald to contain more than 40, 000 Italians and has a considerable element of Greek and other Eastern European peoples." ${ }^{(8)}$ And writing in 1898, an anonymous historian stated: "The Irish element in Buffalo is also very Iarge."

The population of Buffalo, by latest United States Census Bureau estimates, is about 600,000 , and it ranks as the thirteenth city in this country by virtue of that population. It includes foreigners and children of foreign-born and mixed parents from all countries. Numerically the largest groups are Germans, Poles and Italians of whom there were, in round numbers, at the last federal census (1930) some 19,000, 27, 000, and 20,000 respectively. Their children born here number 60, 000 Poles, 60, 000 Germans and 32,000 Italians. 
(5) The Factor of Typicality: In most respects

Buffalo is then a typical industrial American city. Indeed it approximates in almost every detail the characteristics which determined the selection of "Middletown" by the Lynds in their study of a relatively typical community in the United States. (The Iynds emphatically caution against regarding Middletown as an outright example of a "typical" American city; it is merely an approximation since there is no completely "typical" cityd

The traits sought by the Lynds were "(I) A temperate climate. (2) A sufficiently rapid rate of growth to insure the presence of a plentiful assortment of growing pains accompanying contemporary social change. (3) An industrial culture with modern high-speed machine production. (4) The absence of dominance of the city's industry by a single plant, i.e., not a one-industry town. (5) A substantial local artistic life to balance its industrial activity, also a largely self-contained artistic Iffe, e.g., not that of a college town in which the college imports the community's music and lectures. (6) The absence of any outstanding peculiarities or acute local problems which would mark it off from the mid-channel sort of American community. After further consideration, a seventh qualification was added: the city should, if possible, be in that common-denominator of America, the Midale West." 
With all the foregoing criteria Buffalo is in practically full harmony. Where it deviates from the norms established by the Lynds - Middletown was a community of some 30, 000 persons, having only a small foreign-born population - it is not that these factors represent a characteristic essential to a typical American city, but rather a group of special conditions necessitated by the goals sought by the Lynds in their particular study. It may therefore be said that on every essential head Buffalo is, in the restricted sense of the word, a typical American community.

(6) Americanization: In a city where the foreignborn and their children are as numerous as they happen to be in Buffalo, the problem of Americanization is bound to arise. Earnest efforts have been made to absorb such groups into American patterns of life. An organization, which seems to have flourished in the second decade of this century, the Civic Education Association of Erie County, New York, was particularly interested in the enterprise. By publications, campaigns, educational activities and the like it endeavored to give stimulus and direction to the Americanization of the foreign element, and, simultaneously, to create among the native populace a sympathetic understanding for the difficulties which foreign-born residents are often obliged to encounter. 
In the ensuing excerpts from some of the pamphlets this organization published, the overtones of cultural pluralism are, it is interesting to note, rather more than implicit. To foster mutual sympathy and understanding the following plan was suggested as part of an Americanization program: "AlI schools to honor with appropriate exercises the heroes of Poland, Italy and other immigrant lands, the children being taught to appreciate the art, music and literature of the countrymen of their foreign playmates...." (12) This stress on sympathetic appreciation of the cultural background and equipment of the foreign element received added force in the words of Edwin A. Rumball, General Secretary of the aforementioned association: "The average immigrant rightly thinks that his language is just as good as ours. He does not enjoy seeing his chilaren losing it and learning a tongue unknown to him. The intimate terms of the home and the deep significance of the terms of the church are dearer to him in his mother tongue than they could be in any other tongue.... America can lose nothing by showing generosity toward the culture of men and women who have given and will yet give much toward the America that is to be.... America must meet these men emotionally as well as academically if she would make them love her." (Italics our own) 


\section{$-45 a-$ \\ EXPLANATION OF MAP}

The heavy red lines indicate the approximate delimitations of areas of concentration by the Jewish population.

The estimated Jevish population within each of these areas (in 1938) is, as follows:

Area

Hamlin Park

Hertel

William st.

Elmwood-Richmond 粰炎类沗

Scattered in other parts of the City
No. of Jews

$$
4,431
$$

4,781

3,578

3,591

1,619
$\%$ of total

Jewish Population

24.5

26.6

20.0

19.9

来米

9.0

(Based on Irap and Tables prepared by Dr. U. Z. Engelman for his census of the Jewish population of Buffalo in 1937-1938.)

The numbers on the map, within the circles, indicate the location of the existing Jewish schools in the order of their establishment.

School

1. Temple Beth El, 153 Richmond Ave.

2. Temple Beth Zion, 599 Delaware Ave.

3. Jewish Community Center Religious School, 398 Jefferson Ave.

4. Buffalo Hebrew School, 323 Hickory St.

5. Congregation Ahavat Achim, 833 Fillmore Ave.

6. Temple Beth David, 626 Humbolat Parkway
Location on Irap

$K-5$

$I-6$

$0-9$

$\mathrm{N}-8$

IM- 11

$I-10$ 
School (continueå)

7. Temple Emanu El, Colvin and Tacoma Aves.

8. Bureau of Jewish Eaucation, (Gerrans Bldg.) Main and Eagle sts.

9. Anshe Zedek School, 85 Saranac Ave.

10. Congregation Beth Abraham,

1045 Elmwood Ave.

11. Congregation Ohel Jacob,

493. E. Ferry St.

12. Workmen's Circle School,

E. Ferry St and Jefferson Ave.

13. High School of the Bureau of

Jewish Education, 277 Linwood Ave.
Location

on Map

C-8

$0-6$

$D-8$

$\mathrm{H}-6$

$\mathrm{J}-10$

J-9

$K=7$ 


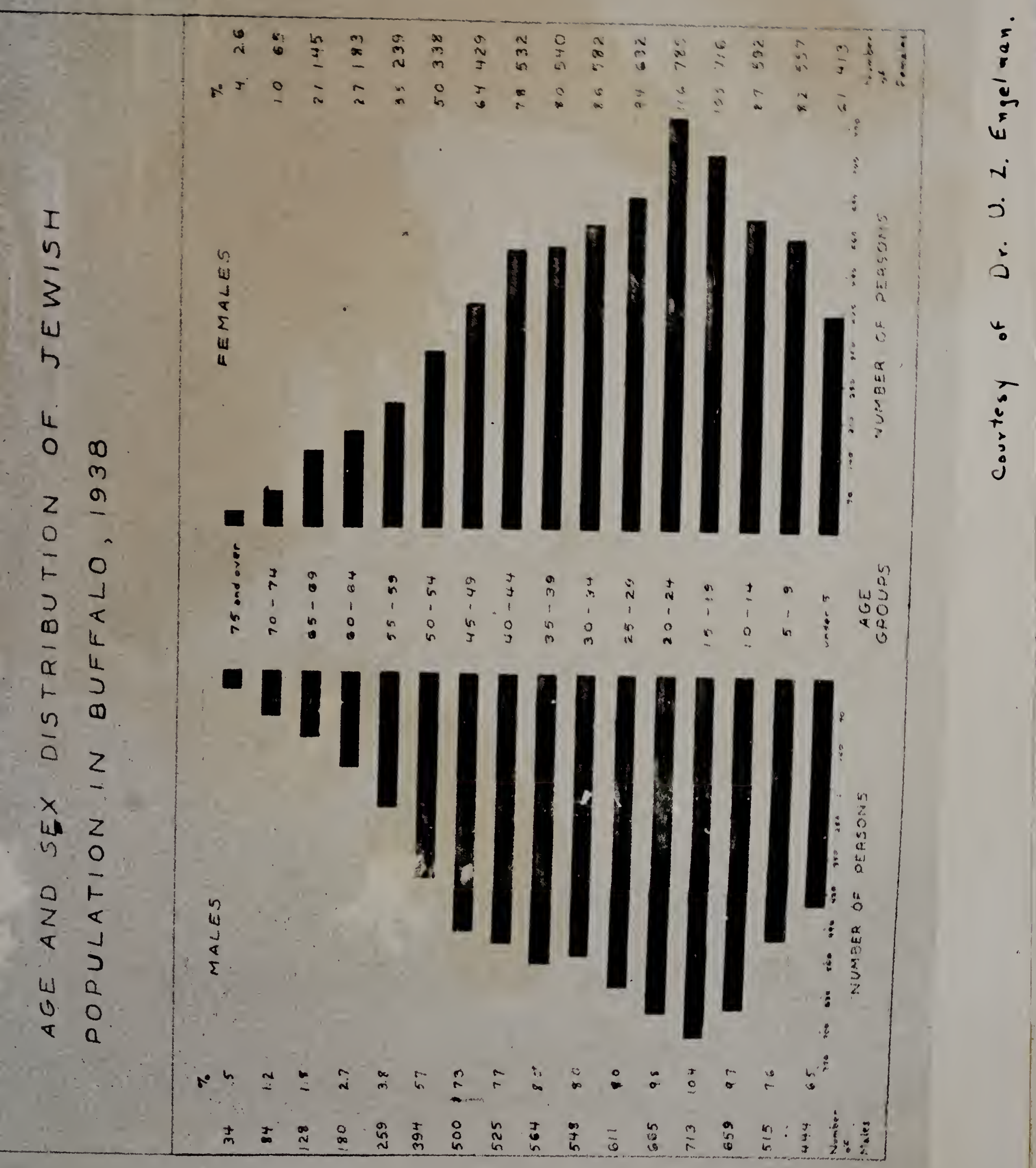


The Jews of Buffalo

(1) 1825-1880: In this city there reside today some 18, 000 Jews. $(14)$ They or their forbears come from every European land but the main sources from which the Jews of Buffalo stem are: Germany, Russia (Czarist), and Austroand Russo-Poland. Of the three waves of Jewish immigration mentioned in the first chapter the Spanish-Portugese never touched Buffalo. The city, therefore, bears no traces or influences of these Jews. Buffalo, which was founded in 1781, and had to endure the vioissitudes of frontier life and did not settle down to becoming an established community till after the War of 1812, had no contact with Jews till 1825.

There was at that time a prominent Jew in this country, a politician, playwright and philanthropist, Mordecal Manuel Noah. "Brought face to face with Jewish misery and rightlessness in most countries of the old World, the thought had matured in him to transplant the Jews to America. In 1825 he purchased a tract of land on Grand Island in the State of New York (in the Niagara River) and issued a manifesto to the Jews of the world to found a government of their own in this refuge to which he gave the name of Ararat." (15) The laying of the cornerstone, a gala affair, was held in a church in Buffalo. The grandiose scheme, however, never got any forwarder. The enterprize fizzled out and was forgotten, but the corner stone still survives as the sole memento of Noah's aream. It can be seen on exhibit in the Buffalo Museum of History. 
The first Jew to settle permanently in Buffalo seems to have arrived in 1835.

coming and grew in number. Most of these early Jews were of German origin. The need for religious inspired them to organize communally. In 1847 the Jacobsohn Society was founded; its main object was: visiting the sick and providing for Jewish burial. It existed for five years.

Meantime Jews now began to arrive from Russia ama Poland. These varied in their life habits as well as in the mode of their worship from the Jews of German origin. Under their initiative the first synagogue in the city, Congregation Beth El (House of God), was established in 1847. As the manner of worship followed by this group was not congenial to the German Jews, these latter organized their own congregation, Beth Zion (House of Zion). "This society," states the chronicler of early Buffalo Jewry, the Reverend Sampson Falk, "deserves special credit for the fact that by it peculiar regard was paid to the sacred duty devolving upon Jewish parents of having their children instructed in the religion of their fathers; the minister being the school teacher, and receiving all the pecuniary income which this afforded, while the congregation furnished room and fuel free of charge."

Toward the beginning of the Civil War, Reform Judaism began to penetrate Buffalo and in 1863 a start toward a Reform congregation was made. In 1864 Temple Beth Zion (Re- 
form) was founded, and the older Congregation Beth Zion, consenting to merge with it, the institution was called "Temple Beth Zion". Membership to this: latter organization was recruited, on the whole, from the ranks of the wealthier Jews.

By 1875 various philanthropic societies had been formed and lodges organized. The origins of Buffalo Jews were by now highly diverse, including: "English, French, Germans, Hollanders, Austrians, Hungarians, Polanders and Russians." Their occupations were as varied as their origins. It is at once edifying and amusing to peruse the list suplied by the Reverend Falk.

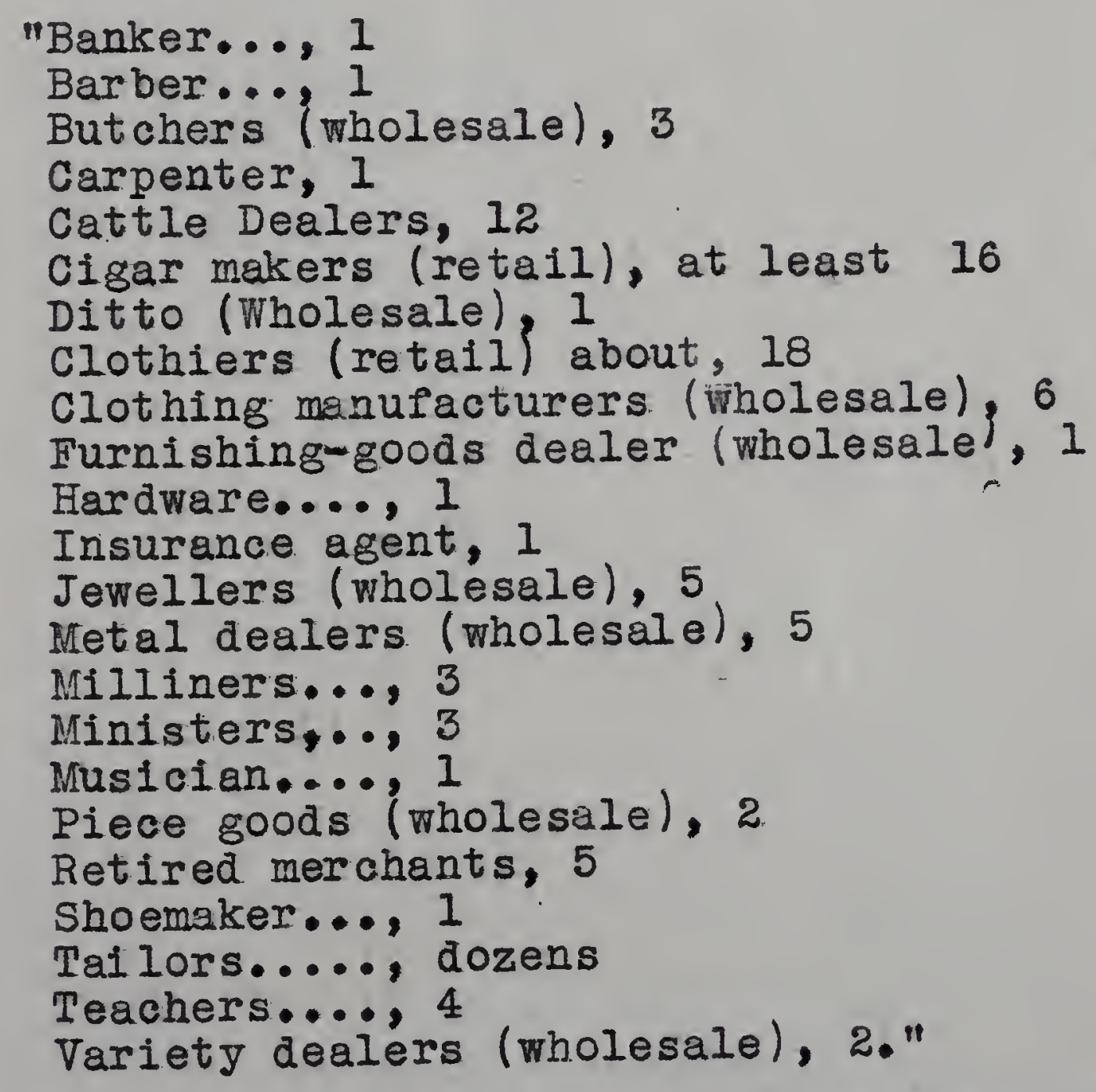

While it was natural for Jews to associate to a great extent with their own groups, it is by no means to be as- 
sumed that they held aloof from the community at large. On the contrary their economic intercourse and civic interest led them to mingle with various elements of the population and, in the course of their worship, to offer up prayer for the welfare of the community and the public authorities.

(2) 1880-1910: The heaviest stream of: Jewish immigration to Buffalo occurred between the years 1881 and 1907. It was part of the tidal wave set in motion by the series of pogroms frequently perpetrated upon the Jews by the Russians in that peridd. Some 10,000 Jews arrived in Buffalo in that interval. (18) They concentrated generally in that area of which William Street was the center and whose approximate delimitations were Michigan Avenue and Jefferson Avenue, and Eagle St, and Broadway.

These Jews usually set up as small shopkeepers and petty traders. Many took to peddling or junk-dealing. Their early days were generally full of hardship but by dint of industry, enterprise and thrift many contrived to advance upward on the ladder of economic success. From these Jews was recruited the rank and file of orthodoxy. It was under their initiative that there was founded the orthodox synagogues which came to dot that area. Among these immigrants of Russo-Polish origin were to be found all shades of radicals, some being former members of the Bund. (19) was the language all East-European Jews best knew and employed in their daily intercourse. But they generally soon 
acquired a working: knowledge of English and attempted to accomodate themselves to the American cultural climate. And what they failed to achieve to perfection in that respect, their children usually accomplished by becoming absorbed into their American milieu. Many of the civic and cultural leaders of Buffalo today are the products of such an early environment and experience.

(3) 1911-1939: Gradually, however, this concentrated area of Jewish habitation began to thin out. As individuals prospered they began to move to the better neighborhoods in the city. From approximately 1920 and onward, new Jewish districts came into being. While Jews may be found in almost any part of the city, there are today four Jewish neighborhoods, so called, not because Jews are necessarlly preponderant in them, but because they contain large clusters of Jewish inhabitants. These areas are: (1) the aforementioned William St. district; (2) Hemlin (or Humboldt) Park; Hertel Section; and (4) Richmond-Elmwood district.

(4) Religious Groups: It is interesting to note that in respect of religious alignment each area has its outstanding complexion. Thus orthodoxy is represented in every area but its stronghold is the William street district. Although Jews are continually leaving this area, it still has seven orthodox synagogues. Hertel section and Hamlin Park tend to affiliate with Conservative Judaism. The Jews who live in these neighborhoods are, relatively speaking, economically 
comfortable and - there is a certain irony in this situation - the tendency among Jews who reach a certain (undefined) level of economic security, if they be orthodox, is to gravitate to Conservatism. Should they happen to rise in the economic scale, they may remain loyal to their previous affiliations, or transfer their allegiance to Reform Judaism. The Richmond-Elmwood section is - on the whole - the wealthiest Jewish neighborhood and it is therefore not strange that this is the center of Reform Jewry. There exist today three Conservative Temples and one Reform Temple. Hamlin Park and Hertel Section have one Conservative Temple each, Beth (House of) David and Emanu El (God is with us), respectively; and RichmondElmwood section boasts one Conservative and one Reform Temple. The Conservative synagogue is called Beth El (House of God) and the Reform, Beth Zion (House of Zion).
(20) The Jewish Schools

(1) "Federation": There are, besides religious institutions, a number of other Jewish organizations, social, cultural and/or philanthropic. of outstanding interest here is the Buffalo Jewish Federation for Social Service, which subsidizes, among other things, a number of Jewish educational undertakings. Indeed with the exception of the four schools maintained by the Conservative and Reform Temples, all the other seven schools receive a greater or lesser measure of financial support from the Federation.

(2) The Communal School: Having in mind the analysis 
of the kinds of Jewish school indicated in the first chapter, we find that there are in Buffalo today types of Jewish schools whose affiliation and character run the gamut of almost all of Jewish social and religious life. There is one school of the Talmud Torah (Study of Torah) communal type: the Buffalo Hebrew School, located in the william St. area, at 323 Hickory st. This school is maintained from funds derived in various ways from the community at large. The biggest part of its income is the annual allotment made it by Federation which contributes about sixty-five per cent of the school's yearly budget.

(3) The "Bureau": The funds allotted by Federation for Talmud Torah and other Jewish educational enterprises are administered through the Bureau of Jewish Education, which, because of its position in the educational set-up and relation to the schools in general, deserves to be considered at greater length in a subsequent chapter.

(4) Congregational Schools: Most of trel Jewishoschools inn Buffaloare of the Congregetional or quasi-Congregational type. The schools maintained by the four Temples are fullfledged Congregational schools, whose financial support and ideological motivation stem directly from the separate, respective institutions. There are, besides, four quasiCongregational schools, so named here, because they are only in part the financial charges of the institutions that 
house them, receiving their funds in greater or lesser degree from Federation through its subsidiary, the Bureau of Jewish Earation. The guiding philosophy of their existence is, however, very similar to that of the Congregational schools.

Belonging to this latter group are the Ahvath Achim (Brotherly Love)ISchool at 833 Fillmore Ave.; the Ohel Jacob (Tent of Jacob) School at 493 East Ferry St.; the Anshe Zedek (Nen of Righteousness) School at 85 Saranac Ave.; the Beth Abraham (House of Abraham) School at 1045 Elmwood Ave. It is interesting to note that these schools are distributed among the four Jewish neighborhoods. The pupils attending these schools are either the children of members of the respective synagogues, or children whose parents cannot affora to pay membership fees (which usually include school tuition fees) and whose education is paid through scholarship grants by the Bureau of Jewish Education.

(5) The Yiddishist School: There exists also a school of the Yidaishist type - the Workmen's Circle School, on East Ferry St. and Jefferson Ave. This school has recently become a ward of Federation on a basis similar to that of the quasi-Congregational schools; that is, it receives a grant for each pupil getting free tuition in it. In accepting aid from Federation, the school had to modify the tra- 
ditionali Yiddishist stand of opposttion to Hebrew and to agree to these stipulations: (I) that Hebrew be introduced alongside of Yidaish in its curriculum, and (2) that instruction concerning Jewish holidays be given added stress.

(6) Sunday Schools: Although almost all the schools conduct a Sunday School department as part of their program, these usually represent a minor, albeit an important, interest. There are, however, two sunday schools which represent the full expression of formal educational effort of the institutions concerned. One is the Jewish Community School, conducted at the Jewish Community Center Builaing (at 398 Jefferson Ave.), operating entirely on a buaget granted by Federation through the Bureau of Jewish Education. It is located in the heart of the William st. neighborhood. Tuition is free and admission is open to all Jews (and non-Jews, too, if any be willing to take advantage of the opportunity) throughout the city. Naturally the greatest number of pupils are recruited from the immediate vicinity。

The second Sunday school is that which is under the auspices of the Reform Congregation, Temple Beth Zion. The pupils are chiefly the children of the membership and the school is financially a charge upon the Congregation. In the last year or two efforts have beeri made to introduce weekday Hebrew instruction. Classes are conducted two days 
a week, on alternate days, after public school hours. Numerically the response to this latest effort has been small but the classes (at the present writing) are still being maintained. The whole undertaking is, however, so recent and so small, that Temple Beth Zion's major educetional orbit must continue to be thought of in sunday school terms.

(7) Higher Jewish Education: It would not be possible to say that a full account of contemporary Buffalo Jewish schools had been presented if we were to omit mention of the High School which was launched this year. This is not the first time that Buffalo has had a Jewish High School. The experiment was made once before to establish one. For various reasons it did not succed. But a follow-thraugh school is needed for those students who exhaust the facilities ana opportunities which the existing Jewish schools offer, so that they may pursue Jewish studies on a higher than elementary level. In an effort to answer this need the Bureau has opened a central Hebrew High School, housed in the building of the Young Nen's Hebrew Association, and meeting twice weekly on alternate days. The location, at 277 Linwood Ave., is quite central, and pupils from all the Jewish schools in the city, who have already acquired a foundation in Jewish subjects, are welcomed. The whole effort is still in the experimental stage and it would be premature to make any predictionsas to its nitimate future or success. 
(8) Adult Education: The Bureau also conducts classes for adults one evening a week, some twenty weeks during the autumn and winter of the year. This enterprise goes by the rather grandiloquent title of "Tarbut (Culture) College of Jewish Studies." The course of study is highly diversified, presumably in the attempt to appeal to a variety of interests. There are lectures on Jewish history, Bible, subjects of current interest, Hebrew, Iiterature etc. There is no fee. The courses are open to the entire adult Buffalo community. Naturally the greatest number of students is recruited from the Jewish group. But non-Jews are also eligible to attend and meny do actively participate in these classes. From time to time non-Jewish lecturers are invited to give a course, particularly when they are people of standing in their field and are available at the time. The career of Tarbut has been a checkered one. It has had its periods of success - measured by the number of registrants - and periods when, for various reasons, it has not been able to attract students in large numbers. But for about ten years now it. has manged to endure and must be a recognized factor in Buffalo Jewry's educational undertakings.

$* * * * * * * *$

This survey merely presents those aspects of Jewish education which are communally organized and formal in their overt expression. It does not include schools maintained through private initiative and enterprise. Nor does it touch 
on important but collateral phases of Jevish education, such as the activities conducted by the Jewish centers: the Jewish Community and the Young Men's and Young Women's Hebrew Association. Nor does it consider the work, also educational in its implications, of various Zionist and fraternal organizations. For in the last analysis, in terms of financial outlay, effort, energy and overt and acknowledged achievement of purpose, in terms of communally concentrated interest and influence, the schools represent the official and maximum expression of Jewish educational effort.

This then is, in sum, the whole educational equipment which Buffalo Jewry possesses and employs in its endeavor to preserve for its posterity their Jewish identity. But it did not spring up in one night. Its emergence was slow, evolutionary, paralleling the emergence of the community itself in its present guise. It may be edifying to trace its development from its inception to its present stages. It will be interesting to note the interplay of environmental conditions and American educational standards and methods with an educational system transplanted from abroad and hoary with tradition.

The following chapters will be devoted to an account of the history of Jewish education in Buffalo to the extent that the available records and the memory of man can succeed in bringing the story into the light of day. 
NOTES

1. Carmer, Carl: Listen for a Lonesome Drum, Farrar and Rinehart, Inc., N. Y. , 1936, p. 46.

2. International Railway Co. Bus and Street Car Guide, Buffalo.

3. "Buffalo in History", article by F. H. Severance, in Christian Endeavor World, June 19, 1919.

4. Published by. J. W. Clement and Co., Buffalo, N. Y., 1920.

5. Severance, Frank H.: "A Historical Sketch of Buffalo", in Civic Section of Buffalo City Directory, 1920, p. 2. (See Note 4, above, for publisher etc.)

6. "The City of Buffalo", article by Frederick J. Shepazd, in New England Magazine, April 1893.

7. See also Directory of Newspapers and Periodicals, N. W. Ayer and Sons, Inc., 1939, p. 593.

8. Severance, "A Historical Sketch of Buffalo", p. 3.

9. Our Country and Its People, A Descriptive Work on Erie County New York, The Boston History Co., Publishers, 1898.

10. Fifteenth Census of the U. S.: 1930, Population, Vol. III, part 2, U. S. Govt. Printing Office, Washington, 1932, Tables 18 and 19, pp. 298-303.

11.Lynd, Robert S. and Helen Merrel: Middletown: A Study in Contemporary American Culture, Harcourt, Brace and CO., N. Y., 1929, pp. 7-8. 
12. "Americanization of Buffalo", pamphlet (probably) issued in 1917 or 1918 by the Civic Education Association of Erie County, N. Y.

13. Rumball, Edwin A.: "Participating Americans", pamphlet (probably) issued in 1917 or 1918 by the Civic Education Assoclation of Erie County, N. Y. , pp. 11-13. See pp. 8 and 9 with reference to a campaign for Americanization (1916-1917), in which Jewish synagogues cooperated with churches. The late Rabbl Louis J. Kopald of Temple Beth Zion was chairman of Mayor Fuhrman's Commission on Americanization.

14. This figure was given to me by Dr. U. Z. Engelman, a statistician, who conducted a thorough house-to-house census of the Jewish population of Buffalo in $193 \%$. It is expected that the study will be published in the near future. No other city in the U. S. has had such a census of its Jewish population. The method usually employed is that of estimates based on certain known factors such as synagogue membership, attendance etc. .

15. Margolis, Max I. and Marx, Alexander: A History of the Jewish People. The Jewish Publication Society of America, Philadelphia, 1927, p. 649.

16. Allen, Hon. Lewis F.: "Founding of the city of Ararat on Grand Island - By Mordecai M. Noah", Publications of the Buffalo Historical Society, Vol. I, published by Bigelow Bros., 1879, pp. 305-328. 
17. The source of information on the history of the Jews in Buffalo between 1835-1880 is derived from "A History of the Istaelites in Buffalo" by Rev. Sampson Falk, in Publications of the Buffalo Historical Society, Vol. I, pp. 289-304.

18. Buffalo Express, May 16, 1909.

19. The "Bund" here referred to is the Jewish Socialist Party active in Russia in the first decade of the twentieth century.

20. The information on the Buffalo Jewish schools of today was derived from inquiries made by the writer of key men in Jewish education in that city, and from personal knowledge as well. Where possible, the information was checked by making similar inquiries of more than one person and comparing the responses. These usually resulted in yielaing information mutually substantiating; the degree of reliability is thus quite high. The main sources of information follow: Dr. U. Z. Engelman, Director of the Bureau of Jewish Education; Mr. I. Lavenda, Principal of the Buffalo Hebrew School; and Mr. S. Rosenberg, Educational Director of Temple Beth Zion. 
CHAPTER FOUR

THE BEGINNINGS OE JEWISH EDUCATION IN BUFFALO: 1848-1900

Having surveyed the history of the Jewish community of Buffalo, and having outlined its educational organizations extant there today, we may now turn our glance backwards and trace the progress of these institutions from their beginnings. Wherever possible, the story has been based upon primary sources, i.e., the minutes of the various organizations and similar documents. Where such material was not available, recourse was had to newspapers, magazines, reports and pamphlets. Information was also gleaned from conferences with persons who were connected with the progress of Jewish education in Buffalo.

The history of Jewish education in Buffalo may be divided, for convenience, into four phases:

I. $1848-1900$

a. Beginnings of Jewish education: Temple Beth El and Temple Beth Zion; private tuition and the "Cheder" (Iiterally, Room; Indicating a form of private school).

II. $1900-1920$

a. Beginning of communal (weekday and Sunday) schools. III. $1920-1930$

a. Shifting of the Jewish population; rise of Conservative congregations and their schools; rise of the Yiddishist school. 
IV. $1930-1940$

a. Era of the Bureau of Jewish Education

1. Efforts by interested individuals to study Jewish educational problems in relation to the community as a whole

2. The 'Survey' of Louis Hurwich

3. Establishment of the Bureau as a project of the Jewish Federation for Social Service 4. Talmud Torah, a ward of the Bureau

5. Extension to other areas; the establishment of small, quasi-Congregational schools.

These dates are by no means representative of a hard and fast division of epochs and no attempt will be made to adhere to them rigidly. But they do indicate, in a general way, the approximate time in which the schools and movements here recorded, began and reached an important stage in their development.

\section{$1848-1900$}

The history of Jewish education in the nineteenth century is essentially the history of two schools, both of the Congregational type. Temple Beth El and Temple Bath Zion established their respective schools, almost immediately after each congregation came into existence. Temile Beth El being the older, must be accorded prior consideration.

To understand the developments that took place in 
Jewish education in this city; to have a better grasp of the changes which evolved in the outlook of the community upon Jewish education, it will be worth while to tell the story of these early schools with as much detail as the record will yield. For Jewish education did not stand still. There are undoubted differences in the character, training and qualifications of the teacher of today, and those of the teachers of former years. Subjects are included in the curriculum of a Jewish school now, which were undreamed of in the nineteenth century. Schooling takes place today in quarters far different from those employed in the past. And all these developments are merely the overt expression of new tendencies and currents of thought which from time to time arose in the community. While the feelings, attitudes and interest of the community in the first stages of its existence cannot be entirely recalled, they may, in part, at any rate, be gleaned from the records it left behind. In so far as it will be feasible, the record will be permitted to speak for itself.

Temple Beth El: Its School

This synagogue is the oldest religious institution in the Jewish community. The early record, as contained in its minutes, does not always give as much information about the school as could be desired. There is, thus, no statement as to a specific educational goal, no clear indication as to curriculum. Nevertheless it does establish the fact that in 
the infancy of the congeggation's life it had already founded a school. The synagogue was organized in 1847, and the first mention of an educational undertaking is to be found in the minutes of May 7, 1848. From the fact that when the school met on a weekday it met after public school hours, it may be inferred that the school was regarded as supplementary to secular education. The record also throws some interesting light on the attainments over and above those of an ability to teach, that a teacher in those days had to bring to his work.

(I) The Teacher: In the minutes of May 7, 1848 is stated that one "Mr. Ansel do give tuition to the chilàren belonging to the Congregation in Hebrew twice a week namely on Sunday from 9 to 12 and Wednesday from 4 to 7." Mr. Ansel must have been a man of some parts, for besides teaching he also acted as cantor, ritual slaughterer and when the occasion required - as "mohel" (one who performs circumcision). Such a combination of functions in one person was not an isolated phenomenon in the mid-nineteenth century. On Feb. 6, 1849 it was moved "that we engage a Competent Person to fulfill the auties of Teacher, Collector and Shamash (sexton) at a salary not to exceed $\$ 150$ per Annum." On May 20 of that year (1849), a motion similar to the preceding one was passed except that the salary was fixed at $\$ 200$. It was further stipulated that the "electee was to be under the control and auspices of the 
Congregation."

(2) Location anä Maintenance: From its founding to 1850 the Congregation met in rented quarters, but in that year the synagogue "moved to a building, which had at various times served as a school and Nazirite Church, 10cated in the center of the block bounded by Main, Pearl, Eagle and Court Streets." At this location the synagogue remained until the growing commercialization of the neighborhood led to the acquisition of a new site, on Elm St. between Eagle and North Division. In September, 1874 the new synagogue was dedicated and there the congregation remained established until 1911. the school was evidently located within the synagogue building.

To meet expenses incurred in conducting a school it was voted (Dec. 17, 1848) to tax members wishing their children taught Hebrew. How big a sum was levied is not indicated. At the same meeting which decided to levy the tax, it was also voted to increase the time of instruction from two to three days a week.

(3) Teacher Tenure: A most vexatious problem in those days was that of tenure. Teachers, it seems, did not hold their posts for long. Again and again the minutes of the Congregation refer to efforts to procure a teacher. The cause for this steady turnover in teaching personnel can only be conjectured. It may have been the dissatisfaction 
of the Congregation with the teacher's performance and the difficulty of engaging a teacher of desirable qualities to come to Buffalo, then a small community. Or it may be that each successive teacher's hopes for an increasing emolument were disappointed, inclining him to go elsewhere. But the fact remains that, whatever the reason, the problem of teacher tenure was ever current. (3)

(4) School Quarters: Although it has been stated that classes were conducted somewhere upon the synagogue's premises, it was evidently felt to be a compromise with necessity. The Congregation hoped for a time when it would be able to establish the school in a separate building. Mention of the matter occurs for the first time on Jan. 14, 1866. "At a Special Meeting.... [it was] moved and seconded that we shall raise money to build a School House..." But the project did not materialize. Nearly three years later the matter was still in the committee stage.

There being no further mention of the project we must assume that it was eventually dropped.

(5) Tuition Fees and Gratis Pupils: Although the school was maintained primarily for the chilaren of members, non-members who could afford to do so could also send their children to the school, paying such fees as the school committee might see fit to levy. As for nonmembers whose circumstances did not permit the payment of a fee, it was "Moved and seconded to give Gratis order 
for admittance to school to children - unable and proved so by examination - to pay for same.

(6) The School Committee and Community Interest: How much interest did the community then display in the affairs of the school and the teacher? There is, of course, no way of answering this question with any positive assertions. The only gauge we have is the occasional reports made by the school committee. This body - presumably - should reflect, in some measure, public feeling.

The first mention of such a body is found in the minutes of April 6, 1860 where it is stated that a school committee of three members was appointed. Its size was later augmented, but there is nowhere any mention of any specific limitation in its numerical composition.

The very existence of a special committee to consider the problems arising from the conduct of the school may in itself betoken a degree of public interest. The committee's reports showed it, on the whole, to be concerned about the progress of the school. At one meeting a Mr. A. Nathan reports that the primary class does not receive enough attention and recommends that the teacher be notified to improve same." At this meeting it was also moved and seconded that members of the school committee visit the school every day (?!), ana report progress at their next meeting. (6)

A further evidence of, interest is the fact that 
deserving pupils were accorded special recognition in the shape of "prizes and presents to Scholars." Also a two week vacation period was granted to the teacher and pupils. This latter was a definite break with the traditional custom which then did not countenance any cessation of Jewish studies the year round.

(7) The School Committee as Supervisor: The teacher's powers were apparentIy under the scrutiny of the school committee, and controversies between the two were not unknown. Thus on March 11, 1883 it was "reported that the teacher did not satisfactorily teach the pupils, and did not obey the instructions as Iaid down by the School Committee. The Rev. S. Bauer stated that inasmuch as he was teacher he ought to have the right to use his own judgment in properly keeping his school. However if his ideas did not agree with those of the school comnittee he would give way and abide by their rulings."

(8) Registration: It would perhaps render the story more complete if it could be ascertained how many pupils were enrolled at the school at any given time. But this information is almost entirely lacking. However, the figures for the period between Feb. 16, 1879 and June 27, 1880 are available and indicate that in that interval some 35 to 40 chilaren were in attendance.

(9) Curriculum: As to what subjects were taught, the record is vague. It merely mentions one subjeat - the 
teaching of Hebrew. But the following report card evidently in use in the school of Congregation Beth El by the 1890's gives us a clue to a more detailed curriculum then in vogue. RELIGIOUS SCHOOL, Congregation "Beth EI" of Buffalo

Report for month ----189

Name of Scholar -..-

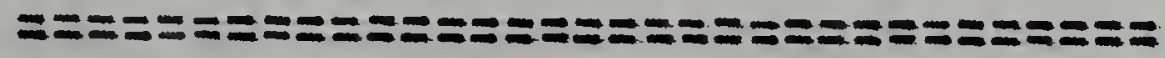

Deportment-- - -

Total no. of school days---

No. of days present--.--.--

No. of days late--n--.---

No. of days absent--n-n---

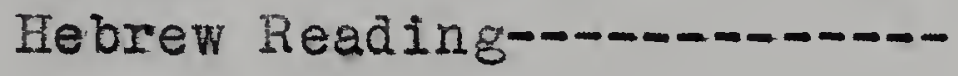

" Translation--.-----

" Religion-- - - - - - -

" History-- -

Remarks-- - - - - - - - - - - - -

Teacher------

Parent-.-.--.---

"Hebrew Reading" probably refers to practice of reading of prayers in Hebrew; "Hebrew Translation" may refer to the study of the Bible by translation from the Hebrew original.

Until 1911 when the Congregation moved into its present location, there were no radical changes in the policy and program of the school. The school was from the first a 
weekday supplementary school of the Congregational type. It seems to have later amplified the school week from three to five days, Monday to Thursday inclusive, and Sunday morning. on this latter morning the curriculum followed was the same as that on weekdays. The sunday school as it exists today at Temple Beth El came later when the school moved to the building on Richmond Ave. But of this and other developments more shall be said later.

Temple Beth Zion

The school intiated by Temple Beth Zion was from the outset a Sunday school. The objective of the school is explicitly stated in a resolution passed in the very first days of the Temple's existence. An entry in the minutes of Oct. 9, 1864 reads: "Resolved: That for the religious education of our children we shall hold as a main object, the establishment of a school to instruct them in our holy religion." (10)

(1) Location: In the beginning the school met somewhere within the walls of the synagogue. For its first house of worship the Congregation, in 1864, acquired by purchase the Methodist Episcopal Church located on Niagara st. just below Eagle St. For twenty-five years the Congregation met in those quarters for worship, and there it conducted its school. In 1890 the new Temple structure, located on Delaware Ave. between Allen and North Streets, was deaicated. But even in its new location classes were held on the premises of the Temple and it was not until 1915 that the Temple Centre, housing the school, was 
built on ground adjoing the Temple.

(2) The Teacher: As with Beth El so with Beth Zion, its teacher had to be a man of some versatility. At a meeting held Nov. 13, 1864, it was "moved that if Mr. Schaner will make application to become Schochat (ritual slaughterer).....Teacher and bring necessary documents to prove his fitness his proposals shall be brought before this Congregation." Eventually as the school grew in numbers, it supplemented the paid teacher with a staff of voluntary assistant teachers, whose work was recognized by means of "presentations" made at school festi(II) vals. Precisely what form these presentations took whether an honorarium or an article as a gift - cannot be determined.

(3) The German Language Question: The early Jewish settlers in Buffalo were largely migrants from Germany. The membership of Temple Beth Zion in its early days included a numerous body of Jews of German origin. Their attachment to the German language was quite strong and for a time the matter of the teaching of German in the school was one of the burning and recrudescent questions of the day. At a meeting, April 4, 1869, "on Motion it was Resolved to retain the teaching of the German language in our school." But by september 1873 a new sentiment had gained the ascendancy. On the 14th of that 
month it was "moved and seconded that the Resolution of the Special School Report to abolish the German language in our school be adopted." The motion was carried 21 to 16. But the matter did not quite end here. On sept. 20 , 1873 a petition was received from nine members asking for a reconsideration of the question. A week later (Sept. 28) a Special General Meeting was held to reconsider the motion of abolition. A motion favoring abolition was again made and carried. Thenceforth advocates of the German language cherished a lost cause.

(4) Sunday School: Nowhere in the early records of Temple Beth Zion is there any express indication that its school was to be a sunday school. That such a school was envisaged, however, seems to have been taken for granted. In any event, perhaps because it was felt that more time was needed for instruction, it was, yet in the early years "ordered.... that Wednesday be retained as one of the school days." (12) (To this day Wednesday after-noon is reserved at the Beth Zion school as a supplementary day of study for the confirmation class - the highest in the school.)

(5) Rules and Regulations: As the school grew older it became evident that questions of policy and administration of all sorts could not be left to random and circumstantial decision. Specific rules and regulations had to be drawn up covering the various details of school control. Certain of these rules had to be modified from 
time to time as the occasion required.

One of the first regulations relates to discipline. Children apparently being the same in every generation, their unruliness in the interval between their arrival and class time resulted in a regulation that one teacher was to be present fifteen minutes before school opening time.

One matter in particular exercised the minds of the members: what to do in the matter of admitting children of non-members. Regulations were laid down from time to time and on April 4, 1880 a Committee of Revision of Rules for admission of non-members' chilaren issued a report. Its principle provisions were that non-members' children already in the school be permitted to remain, children of parents unable to be members but who worship and attend Temple services be admitted to the school, but their number must never exceed 20. Later, in the light of changing circumstances, these rules had to be modified. But it is in point to note here that the essential principle of admitting to the school children of those who could not afford membership was never relinquished.

(6) Enroliment: It is of some interest to note the number of pupils enrolled in the school in the period under consideration (1864-1900); naturally the enrollment must have varied annually and the record does not furnish complete information. But occasionally the number of registered pupils is given. Thus on sept. 14, 1891 the school 
was reported opened with 78 pupils in attendance as against 108 in 1890. And on oct. 28, 1895 there were 90 pupils of whom 32 were children of non-members.

(7) Supervision of the school: In accordance with a policy which seems to have been established early in congregational schools - weekday and Sunday - the rabbi was expected to exercise a supervisory role in the functioning of the school. To him the school committee would turn for whatever information it desired about the school and it was also incumbent upon him to conduct the school in harmony with the rules and wishes of that body. On Jan. 31, 1895, a resolution was adopted by the committee asking Dr. Aaron (then rabbi) to furnish it a written report from each teacher as to how many pupils were on the rolls; how many were children of members and how many of non-members; the average attendance of each class; work to be covered; extent of progress; that Dr. Aaron as superintendent be asked to offer his opinion, based on observation and experience, as to how the sunday School shall be conducted in the future and what improvements could be made; and that he hold meetings with the teachers to discuss matters pertaining to the school.

(8) Curriculum: One result of the adoption of this resolution was that Dr. Aaron submitted a curriculum to the committee. It indicates the scope of instruction as well as the gradation of subject matter then current. It is not entirely free from a certain vagueness; nevertheless it merits 
scrutiny. The work is divided under three headings: Hebrew, history, and Judaism and ethics.

Hebrew

Ist grade- Primer

2nd grade- Reading (prayerbook)

3rd grade- Translation of Evening Prayer

4th grade- Translation of Morning Prayer

\section{History}

lst grade- Creation to Moses

2nd grade- Moses to Kings

3rd grade- Kings to end of Babylonian Period

4th grade- Post-Biblical History

\section{Judaism, Ethics}

Ist grade- Scriptural Questions

2nd grade- Psalms and Religious Instruction

3rd grade- Psalms and Dictated Instruction

4th grade- Proverbs and Moral Lessons

On Sunday mornings - Services with a sermonette by Dr. Aaron

(9) The Voice of the Teachers: From time to time the teachers made known their points of view too. On one occasion it was reported that they were of the opinion that the textbooks then being used were not satisfactory; they urged that an effort be made to procure better books. They also asked that reference books be made available to them. They also. stated their decision to meet with the superintendent (rabbi) from time to time to discuss affairs of the school.

This, then, is the story of Temple Beth Zion's educational efforts until the beginning of the present century. Whatever the limitations of a Sundey School, it may none- 
theless be sald that within these limitations Temple Beth Zion was striving toward an ever improved school. As time went on, significant changes of policy occurred. These will be indicated subsequently.

Private Teachers and the "Cheder" (Private School)

For those members of the Jewish community who had brought over with them from Europe notions of an intensive and extensive Jewish education, the curriculum of Temple Beth El's school must have seemed very meager and that of Beth Zion entirely out of the question. For them and for such as were barred from enjoying the educational facilities of either school, whether by reason of distance or non-membership, the only other alternatives were either the engagement of a private teacher to give tuition at the pupil's home or - the "cheder".

The private teachers can be disposed of briefly. They were individuals of varying attainments who imparted instruction at the home of the pupil at certain intervals during the week. The course of study varied, depending on teacher and pupil and parent demand. Where this latter was at a minimum, instruction was limited to the teaching of mechanical reading of Hebrew with a view toward achieving a facile fluency in reciting daily prayers, supplemented by instruction in excerpts from the Pentateuch in Hebrew. Under happier auspices - where the teacher possessed requisite qualities of ability to instruct and the desired concommitant of knowledge; and the pupil was amenable to instruc- 
tion; and the parents demands were more ambitious - under such a combination of circumstances much more could be achieved. Then the minimum amount of instruction might be amplified to include wide selections from the Bible particularly Pentateuch and Prophets - and, on occasion, some study of "lalmudic literature. All these subjects the pupil would be taught from the original Hebrew texts, so that with knowledge of content came also knowledge of language.

To what extent, precisely, private teachers were engaged in Buffalo in the previous century, there is no way of knowing. The best that may be conjectured is that the vogue did exist - the writer swoke with Buffalonians who received instruction through this medium - and, though in decreasing measure, still exists.

The word "cheder" (pronounce ch as in German doch) is Hebrew and means a room; from which we may correctly infer that it was the practice of the teacher to conduct the class in a room in his house. Today it is a disappearing phenomenon. But at one time the cheder had quite a vogue. and in East-European Iands (whence it was transplanted to the United States) it was for centuries almost the sole form of elementary and higher Jewish education.

It is not in point to trace here in any detail the history of the cheder as a factor in Jewish education. A good account of it may be found in a previously referred to work, Dr. Gamoran's Changing Conceptions in Jewish Education. For a parallel to it in the field of general ed- 
ucation in modern times we might refer to the Dame Schools which existed in England in the nineteenth century.

Until the establishment of the Talmud Torah, the cheder conducted by a Mr. Diamond - he is still alive, and though of advanced years, quite alert intellectually - was the chief source of Jewish instruction for the chilaren of those Jews who Iived in the William St. area. It was eventually located, after various changes of residence by $M$. Diamond, on Spring near William st., and seems to have been touched by the influences working toward improving the cheder as an institution of instruction. The classes were conducted in a large room, well lit, and passably clean. It was furnished with a blackboard - not part of the standard equipment usually to be found in a cheder - and the pupils sat on long benches with a narrow slanting desk on which to rest their books. Discipline was maintained by stringent methods. Chilaren were divided into classes. Each class met for about two hours daily, either from 4 to 6 , or 6 to 8 P.M. The subjects taught were reading of Hebrew prayers and Pentateuch. The cheder suffered a temporary eclipse with the opening of the Talmud Torah, was revived for some years once again in 1909, moved to the western (Elmwood) section of the city in 1920, and with the rise of the Congregational schools, expired. (16)

Since then individual men have trled to launch a cheder but the existing schools have thoroughly supplanted them. As a force in Jewish education the cheder is practically ex- 
tinguished.

*1*********************

Essentially then Jewish education in Buffalo in the nineteenth century was marked by Congregational enterprise. The community-wide effort did not get under way until the last decade of the century, when the Sisterhood of Zion founded a community Sunday School and, somewhat later, the Talmud Torah was organized. Of these we shall tell in the following chapter. 
NOTES

1. All references to Temple Beth El's minutes were taken directly from the minute books of the Congregation. 2. From a brief historical symopsis of Temple Beth EI by its erstwhile Rabbi Reuben J. Magil, included in the souvenir program of the 9lst Anniversary Ball of the Temple, 1938.

3. See e.g., Temple Beth El's minutes of Mar. 10, 1854; Apr. 8, 1860 and Apr. (?), 1862. Also Oct. 8, 1865.

4. Minutes of Oct. 25 and Nor. 9, 1868.

5. Minutes of Apr. 13, 1879.

6. Minutes of May 25, 1879.

7. Minutes of July $20,1879$.

8. Minutes of Aug. 5, 1879.

9. Minutes of June $27,1880$.

10. All references of minutes of Temple Beth Zion up to 1890 are those of the Congregation proper; those after that date are taken from the minutes of the school Committee.

11. Minutes of Dec. 3, 1871.

12. Minutes of oct. 16, 1870.

13. Minutes of oct. 1, 1878.

14. Minutes of May 22, 1895.

15. Minutes of Nov. $9,1896$.

16. Information on private teachers was gleaned from conversations with Buffalonian Jews who received private tuition. On the "cheder" Information was obtained from one-time pupils and from Mr. Diamond who conducted the cheder. 


\section{CHAPTER FIVE}

\section{TWENTIETH CENTURY DEVELOPNENTS: The Rise of}

\section{the Communal School}

The first organized educational efforts of Buffalo Jewry were, as has been indicated, confined tc gongregational enterprise. However, toward the close of the nineteenth century, new currents began to be discernible. Jews were coming to feel that their responsibilities could not be canalized into the narrow confines of Congregational interests alone.

Jewish communal activity is not the outcome of mere random philanthropic motivation. It is grounded in a definite principle which is imbedded in Jemish life itself. "All Jews," runs a maxim in the Talmud, "have a mutual re(I) sponsibility to each other." It is this ancient aphorism, among other things, that impels Jews to assume the often onerous burden of communal undertakings wherever a Jewish community exists.

In the educational field in Buffalo this wider-thanparochial interest first found practical expression toward the end of the nineteenth century. And it led to the establishment of the Jewish Community Religious School.

The Jewish Community Religious School

(I) Aim: This school is a Sunday School. It is rather unique in that where Sunday schools are usually an integral part of a congregation, it is not directly affiliated with any such organization. As the result of a fire which occurred some years ago, the early records of this school and 
its progenitress, the Sisterhood of Zion, were destroyed. But the following statement in the Buffalo Jewish Review epitomizes what must have been the motives and aims which led to the establishment of the school. "About 25 years ago (1896) a group of Jewish women known as the 'Daughters of the Star' and 'The Sisterhood of Zion' realized that the spiritual education of the majority of the Jewish children on the east side of the city (the William st. area) was being sadly neglected. Year after year boys and girls were growing up with scarce an idea of Judaism and the Jew's place in the world. These farsighted and conscientious women knew that if something were not done to remedy this threatening evil, in years to come the ethical and moral standards of the Jews would become demoralized, and instead of winning the respect and approbation of their neighbors, the Jews would be scorned and treated with contempt."

(2) The Sisterhood of Zion: This organization was founded on Aug. 16, 1891, by Dr. Israel Aaron, then rabbi of Temple Beth Zion (Reform). The broad aim of the group whose Reform background should be borne in mind - was philanthropy and uplift work among the economically lessfavored Jews of the east side. Its interests were numerous and included, besides the religious school, kindergarten classes, classes in sewing, dancing, dramatics, the acquirement of social graces and the lake. 
The first location in which the Sisterhood carried on its activities was a rented house on Walnut St.; it came to be known as the Home. In 1892 a transfer was made to Spring St. A year later a house at 456 Jefferson Ave. was purchased. After three years the Sisterhood, under the pressure of its expanding activities and the increasing number of people taking advantage of its facilities, rebuilt the Home - which had come by now to be known as zion House - to meet the growing needs. By 1911 the remodelled Home was proving inadequate and it resulted in the erection of the present Jewish Community Center Building at 406 Jefferson Ave. (3) pleted and all activities transferred to $\mathrm{I}^{4}$.

In its early days the Sisterhood assumed financial obligation for the maintenance of the school. It raised funds through membership dues and various undertakings. Eventually the expenses of the Sisterhood - which wes one of the nuclear organizations from which the Jewish Federetion for social Service developed - were taken over by the Federation. But the welfare of the school and the Community Center as a whole continued to be the main concern of the Sisterhood. (*)

(3) The School in Its Early Years: As has been indicated, it is well to remember that the school, launched about 1896 as one phase of a settlement venture, was sponsored, in the main, by Jews from Temple Beth Zion. Hence 
the viewpoint in the first days must have been largely Reform. The curriculum included the usual sunday School staples: Bible stuaj, ethics, hymns, history. This latter subject had as its terminal date, 1492, the year of the expulsion of the Jews from Spain. No attempt was made to teach modern history. A textbook was used which employed the device of pointing each lesson with a moral. The teaching staff consisted of volunteers; but at times, when teachers were sent to attend conventions, their expenses were paid by the school.

To foster Americanism was an implicit aim of the school and to that end an assembly was held on the sunday between Iincoln's and Washington's birthdays. The program consisted of patriotic exercises and the children were presented with flags, sang songs and were addressed by a speaker on apatriotic theme. The speaker was often nonJewish. This was intended to show the common bond of Americanism which cuts athwart religious lines.

(4) The Administration of Samuel Harris: The supervision of the school was lodged in the hands of men of good will who gave voluntarily of their time and energy to the welfare of the school. Bearing in mind that these men had no special training for this type of work, it must be conceded that they did commendably well. From 1896 to 1909 the supervision passed into several hands. But in 1909 Samuel J. Harris (presently a member of the Appelate 
Division of the Court of New York) became supervisor. He held the post until 1925. Under his direction the school moved forward.

His first concern was to improve attendance, which, when he came, showed wide discrepancies in comparison to registration. Thus in his report after the first year of his incumbency, he pointed out that the registration numbered 275 but that only 110 pupils attended in the first month (Sept. 1910). He recommended that efforts be made to secure the best frcilities in rooms, teachers, books and methods,

Himself a volunteer, Harris nevertheless realized that, in view of the extent and complexity of Jewish subject matter, trained teachers were necessary; and these were seldom available from the ranks of volunteer teachers. Toward the end of his tenure he had succeeded in introducing a paid teacher system. He was moreover aware of his own shortcomings as an educator, and in his last years at the school, instituted a system of supervisors - professional teachers, who were presumably well grounded in pedagogy and could therefore assist the teachers.

In a file at the community Center there is a copy of a resolution arawn up in honor of $\mathrm{Mr}$. Harris. It is not datea. Its contents leave no doubt that his efforts were appreciated. When he assumed his posst - runs the gist of the resolution - the attendance was small. Under him and due to his ability the school outgrew its quarters and when larger rooms were provided the school grew to outstrip even them. 
As to the value of the school, the resolution has this to say: "The beneficial results which this school has brought to the Jewish community are self-apparent. Better children, better young men and women, better citizenship, are natural resultants."

(5) Under Jacob Tick: $\left.{ }^{*}\right)$ When Mr. Harris relinquished the post of superintendent in 1925, he was succeeded by Jacob Tick. Under him the school made further strides forward. His incumbency marked the coming of age of the school. He began to keep cumulative records and other administrative appurtenances: teachers' reports, lesson plans, report cards. He gave special attention to the staff. When vacancies occurred in the faculty he tried to replace them with trained teachers (i.e., recruited from the public school).

The curriaulum in vogue under Mr. Harris was carried over into Mr. Tick's regime. But toward the latter part of his superintendency he introduced certain changes. The ceremony of graduation hed been instituted by Mr. Harris; Tick continued the ceremony but added to it the granting of diplomas. He also attempted a post-graduate class. Its purpose, however, appears to have been more to impart social polish than Jewish content. Its life span was short; it lasted only two years.

Of more significance was the change in outlook which these latter years witnessed, resulting in a concommitant modification in curriculum. Whereas the school had been 
hitherto animated - not formally, to be sure, but in effect - by a Reform attitude: which is tantamount to saying that its outlook was non-national: it now began to veer toward a nationalistic approach. The new standpoint was manifested by the institution of special programs and assemblies for Chanukah (Feast of Dedication) and Purim (Feast of Lots). These assemblies wauld first be held with the children and then the program would be repeated in the evening for the parents. These celebrations became an annual social event in the community.

There were further changes in emphasis. History, which had been taught up to the expulsion of the Jews from Spain in 1492, was now taught right down to our own times. Newer and more modern text books were introduced. A leaning toward Zionism was manifested by the teaching of Palestinian songs.

Toward the end of Mr. Tick's administration, the school entered upon a new phase of its existence; in 1932 it became a constituent of the Bureau of Jewish Education. The significance of this development will be treated. in the following chapter.

The Buffalo Hebrew School (Talmud Torah)

(I) Beginnings: Until 1904 there existed no communal, Jewish weekday school in Buffalo. The William st. area, in which was settled the largest, preponderately Orthodox Jewish group, contained a "cheder" and private teachers (see end of Chap. IV). But it was patent that neither ar- 
rangement was adequate or satisfactory. In response to the felt need for a school that should provide a more ample, Orthodox Jewish educetion, a number of community-minded individuals, in 1904, established the Talmud Torah (known in English as the Buffalo Hebrew School but generally referred to by its Hebrew namel at 323 Hickory St. in a roomy building. The school has never changed its location.

The parents were responsive from the first. The enrollment - there are few recorded figures available - as reported by former pupils, who attended classes in those early days, reached between two-and three hundred pupils. Until 1930 this figure was fairly constant.

The first principal of the school was a Mr. Blumenthal, a man who seems to have had the power to attract young people to him. He had a staff of three teachers. To popularize and publiclze the school he employed various devices - meetings, clubs and other means of making the community aware of the school's existence. When he left in 1908, he was succeeded by various men in turn - who did not, however, retain their post long. The next principal to hold the position for a considerable period of time was Mr. Ephraim Lesitzky, who came to the school in 1912 and staid for four years. (8)

(2) Financing: The school was supported financially by various methods. There was a dues-paying membership recruited from the Jewish community at large. Besides there was an income from tuition fees, paid by the parents of 
pupils who could afford the outlay. (Pupils whose parents were not in a position to pay the fee were granted tuition gratis.)

A further means of financing the school was found in the form of a species of voluntary communal tax. For every fow that was ritually slaughtered, two cents were paid to the "shochet", (slaughterer), who turned over sums collected in this wise to the school. It is estimated that from this source an income of approximately three thousand dollars a year was derived. This tax was levied by every shochet throughout every district in the city. Thus, though the Talmud Torah was located in the William St. neighborhood, it was a financial responsibility of the entire community. Another fund-raising device was the sale of "matzo" (unleavened bread) before and during the Passover season. With the goodwill of the community the Talmud Torah came to exercise a monoply over the sale and distribution of this commodity and realized thereby an aditional annual income of some fifteen hundred dollars.

Yet another method in vogue in the early days of the school was the fair and bazaar held annually on the Talmud Torah's premises. Additional revenue was derived from this source.

(3) Language of Instruction: English has been for many years, and still is to this day, the language of instruction. But in its early days, there was considerable shifting 
between English and Yidaish, now the one, now the other being established by the Board of Directors. These changes apparently were instituted without too much reflection either at the whim of a member of, the Board or by wish of the principal of the day. (10) healthy and harmful to the stability of the school and its pupils, the Board eventually came to recognize; and it incorporated its views on the matter in a Declaration of Principle, framed by its Board of Education. (II) Although this document was drafted about ten years after the establishment of the Talmud Torah, it no doubt expresses the alm of the school from its inception.

(4) Aims: The Declaration of Principles follows. It is not strong in specific proposals, although that is one of its avowed intentions. But the general spirit which animates it is clear beyond all dubiety. Unlike the minutes of the Board of Directors which are kept in English this document is engrossed into the record in Yiddish. (The translation is that of the present writer.)

We, the Board of Education of the Buffalo Hebrew School, having regard for the status of the TaImud Torah, moreover, having regard for the fact that every chan ge of principal involves a change in system resulting in a loss of previous achievement, to the detriment of the pupils and the good name of the school; - Therefore let it be resolved, once and for all, to make clear the goal and purpose of the 
education of the pupils of the Talmud Torah and also to lay down along clear lines a course of study so that should a new principal or teacher be engaged he will know what are our requirements and what we aim at to the end that the pupils progress rather than - regress.

"The one purpose of our Talmud Torah is to raise our chilcren, sons and daughters, in a Jewish and fully Orthodox aligious way. All that they learn shall be so taught that they may grow up to be honest, religious and God-fearing folk; that they may understand and love the Jewish people and the Jewish religion.

"They should know all Jewish traditions and customs. "They should love and cherish the Jewish faith and take pride in their Jewish antecedents.

"They should also know and understand the order of the prayers and Jewish customs and ceremonies of the year round; so that when they enter the synagogue they shall feel quite at ease therein.

"And no matter wheresoever they may find themselves, they should have the knowledge requisite to a dignified defence of the Jewish people and Jewish faith."

As to the language issue, the Declaration recognizes the circumstantial necessity for carrying on instruction in English. Yet it would not like to see Yiddish regarded as an utterly prohibited commodity in the school for "it is very desirable that a Jewish child be familiar with it." (12) 
(5) Curriculum:

(13)

week, Monday through Saturday, for about two hours daily. (Monday to Friday they met after public school hours.)

Later the class on Saturday was discontinued. The subjects taught were Hebrew prayers and the Bible in Hebrew. There was no recognized "terminus ad quem" for the studies. Pupils simply attended until they exhausted all the possibilities of the school; or until they grew too old to attend or until they lost interest, and then merely dropped out. It was not till late in the $1920^{\prime} \mathrm{s}$ that a limit was put upon attendance with a formal graduation as a goal.

(6) Affiliation with Federation: In 1921 agitation was begun to induce the Bufialo Hebrew School to affiliate with the Jewish Federation for Social Service (the agency for collective Jewish philanthropy in Buffalo). Many obstacles stood in the way of such an affiliation. But the biggest was the fear of the school's directorate that the orthodoxy which the Talmud Torah stood for might in some viay be jeoparaized. Federation was to some extent in the hands of Reform Jews. (14)

The tter proceeded slowly. Two years later it had. reached a point where a conmittee was appointed to investigate and report on affiliation with Federation. (15) Almost another jear went by before the amalgamation actually occurred. On Nov. 10, 1924, "Nr. Charles Polakorr reported that at a meeting of the Board of Governors of the Jewish 
Federation it was decided that the sum of 10,000 dollars shall be given toward the amalgamation of same, with the understanding not to interfere with the educational supervision of the school, and upon this report it was unanimously decided to accept the proposition of the Jewish Federation regarding the amalgamation." (16)

This affiliation with F'ederation had two concommitant results: (1) Tuition fees were abolished. (2) It paved the way for the absorption of the Talmud Torah into the orbit of the Bureau when that organization was established in 1930. From then on the fortunes of the school became closeIy bound up with those of the Bureau and its later progress must therefore be considered in relation to the Bureau, with which the next chapter will deal.

$* * * * * * * * * * * * * * * * * * * * * * * * * * * * * * * * * * * * * *$

It is thus apparent that the first two decades of the present century witnessed a manifestation of communal enterprize in education. It is of some interest that thereby two extremes of Jewish religious life - Orthodox (Talmud Torah) and Reform (Community Center School) were brought into juxtaposition. And as both converged upon the selfsame area William St. - it may well be that herein lies the explanation of the institution of a Sunday School in the Talmud Torah itself.

The Sunday School of the Talmud Torah

No one seems to know exactly when this school was or- 
ganized. It is quite certain, though, that it was established in the early days of the Talmud Torah's existence. The purpose of its founding is also not quite clear. There are at least two schools of thought on the matter. One has it that it owes its existence to the fact that the community Center school alone could not accomodate all the children of the neighborhood, and another school was a sheer spatial necessity. The other school of thought states its case on ideological grounds. It suggests that the Reform sponsorship and philanthropic origin of the Community Center school tended to make it somewhat suspect to the orthodox parents, and thus led to the establishment of the Talmua Torah sunday School.

Be that as it my, this school existed till about 1929. At its height (1920-1927) it had a putative enrollment of about 300 pupils. Its curriculum laid special stress upon orthodox religious instruction. Its financial obligations were met by the Talmud Torah. At the annual closing of the school deserving pupils were given awards. From all reports, the school enjoyed a considerable degree of popularity in the neighborhood.

In 1929 the Sunday School was discontinued. The Jewish population had been steadily leaving for other parts of the city, and it was felt that the Community Center school which had meantime begun to lose its Reform aspect - was adequate to the needs of the area. 
Congregational Schools: New and Old

Although the early part of the period under consideration (1900-1930) was characterized chiefly by communal effort, it was not entirely devoid of new congregational

\section{initiative.}

(1) Congregation Ahavat Achim (Brotherly Achim)! (*) Located on Fillmore Ave. near Broadway - in the heart of the Polish business district and on the fringe of the William St. area - this Congregation had first granted part of its premises (circa 1900) to Mr. Diamond (see Chap. IV) who conducted a private school there. But in 1910 the Congregation remodelled its building and took over the conduct of the school. It employed two teachers and had an enrollment of some 60 pupils. The expenses incurred in the maintenance of the school were met from the tuition fees paid by the pupils; and when the income from this source was insufficient, the Congregation covered the deficit.

In 1913 a new synagogue building, almost adjacent to the old one, was erected, and the school was housed in the chapel of the new building. But by then the shift of the Jewish inhabitants from the vicinity had begun, resulting in a diminshing enrollment. Thenceforth the school employed only one teacher. It had to struggle to meet the financial outlays and was ultimately compelled to turn for aid to the Talmud Torah, which answered the appeal by constituting the needy sohool a branch of its own. (18) 
This arrangement lasted till 1920 when the Talmud Torah decided to discontinue its assistance to the Fillmore Ave. school as "most of the pupils of that Branch are children of Parents who are able enough to support a teacher without any necessity to be a burden on the community." (19) Subsequently the Talmud Torah was again appealed to for aid, which it granted. But by then (1929) both the Talmud Torah and the Fillmore Ave. school had been drawn into the orbit of Federation and thereafter, of the Bureau.

(2) Congregation Beth El: With the dedication of its new building on Richmond Ave. and the installation of Dr. J. H. Landau as its rabbi, in 1911, the Beth EI school was launched on a new basis, having a Sunday as well as a weekday school. Dr. Landau stood in a dual relationship to the school. He was its superintendent and, in addition, had charge of the confirmation class on Sundays and taught Hebrew in the weekday school.

By June 1911, the Sunday School had 176 pupils who were divided into five classes. Teachers were evidently volunteer workers. The weekday school had a more modest. registration of about 40 pupils. (20)

There may have been some opposition to Dr. Landau who manifested Reform tendencies. It had always been, and still is, the pride of this Congregation that it is the "steadast champion of traditional Judaism." (21) In 1913 Rabbi Drob, whose leanings were definitely "traditional", 
became the spiritual leader of the Congregation. He endeavored to lay the foundations for a more traditional course of study than had apparently been given by his predecessor. Prayers and the Hebrew language and Pentateuch were included. The school grew in numbers. As time went on and new rabbis took over the school each in turn made his own impress. Each had his pet ideas for making the school more attractive and the teaching more effective.

In recent years the school has had to adopt an involved schedule of attendance in its weekday school, whereby some classes come twice a week, some three and some four days a week. This: was caused by the fact that many pupils who lived at a great distance from the school found attendance four days a week a difficulty. The result was that pupils were dropping out of the school. The revised schedule - now in vogue - was designed to remedy this situation.

(3) Temole Beth Zion: To make its Sunday School a more effective institution was one of the prime endeavors of this Temple. Its school Committee drew up various regulations at different times with this view in mind. To advise the parents of their children's work and punctuality it ordered that reports be sent out monthly. (23) compensation for teachers providing for annual increases up to a stated maximum, which was reached after seven years of service with the school. (24) governing practically every phase of the conduct of the 
school was drafted, covering administration, promotion of pupils, aniform system of marking, discipline and other pertinent matters. (25)

One of the problems which exercised the minds of the committee was that of Hebrew instruction (which in Beth Zion then meant learning the translation of short Hebrew prayers). Should it be optional, compulsory or abolished? After protracted consideration of the problem (from 1911 to 1915) a compromise was reached whereby the teaching of the subject was abolished on Sunday; but instruction in Hebrew was to be provided on an optional basis. To that end, Rabbi Kopald was meantime working on a plan for voluntary instruction which he later submitted; the schedule he drew up utilized Saturday mornings, the hour between 9 and 10 on Sunday mornings (just preceding the beginning of regular classes on that day) and an hour on Weanesday afternoons, for that purpose. (27)

To improve teaching efficiency a training school with courses in the psychology of education under a Miss Adele Land was established in 1923. (28) those of the faculty who would enter this training school and successfully grasp the work would receive remuneration in accordance with their ultimate increased efficiency." In general it was felt that to attract good teachers and insure a greater degree of permanence in the staff, better salaries must be paid. 
Two significant steps were taken by Temple Beth Zion before 1930. One was that steps were begun leading to the reestablishment of Hebrew as an integral part of the curriculum. The other was the creation of the post of educational director. A recommendation was made to the Board of Trustees "that a graduate, trained or experienced principal be secured to give full time to our religious school and other Temple activities at a salary not to exceed four thousand dollars per annum. Unanimously carried." The Board quite patently acted favorably on the recommendation and engaged a Mr. Bernard Fischlowitz who held the post for two or three years.

In $1935 \mathrm{Mr}$. Samuel Rosenberg became educational director. Under him the school went further in the matter of Hebrew instruction than it had hitherto. Besides the Hebrew classes which were conducted on sunday mornings as part of the regular sunday School program, a two-day-aweek school was instituted in 1938 for those who wanted to receive additional instruction in Hebrew. It was a very modest - but for Temple Beth Zion, a very novel - venture, with a small enrollment of 40 pupils (as against 472 on Sunday). (32) A further step was the development of a postgraduate class, which had been contemplated even before the coming of $\mathrm{Mr}$. Rosenberg. (33) gram was actually implemented.

***********************************

It has already been indicated that from (circa) 1912 
and onward, the Jewish population which studded the William St. aistrict began to move to new areas within the city. In the post-war years the number of families leaving the east side mounted steadily. And by the early -20 's there were enough Jews in the Hamlin Park and Hertel sections to establish a Conservative synagogue in each. Temple Beth Davia, on Humboldt Parkway, was founded in 1923 and Temple Emanu EI (Hertel) now at Tacoma and Colvin Aves., in 1924. Soon after they were founded they each established a school adhering to the customary Congregational pattern: both schools were maintained by their respective congregations, under the surveillance of a school committee; both had as one of their motives the desire to foster a loyalty to the synagogue in the rising generations, and both adhered to the curriculum usually followed in Congregational schools.

(4) Temple Beth David: ${ }^{*}$ When newly organized in 1922, this congregation acquired for its first site a house at 652 Humboldt Parkway. Almost from the start the building was used for a twofold purpose: as a house of worship and a school. It had evidently been decided as a matter of course that the Congregation should maintain a weekday school. In the first year some forty pupils enrolled and one teacher was engaged.

Meantime plans were set afoot to build a synagogue and the cornerstone was laid at 626 Humboldt Parkay in November 1924. (35) The building was completed in 1925. It pro- 
vided school facilities which were far from ideal but superior to those afforded in the first location. The registration increased and by 1928 had reached 70 pupils.

With the engagement of Dr. Engelman in 1929, the school entered upon a new phase. Hitherto only boys had been admitted. At his suggestion girls too were permitted to enroll. A kindergarten class was also introduced. These steps, together with other factors, resulted in an increase in registration, which, within a few years, amounted to 175 pupils. As the enrollment mounted the staff was augmented and by 1935 it included four teachers.

By 1936 it was borne in upon the Congregation that the space provided for school purposes within the Temple proper was inadequate. A drive was launched and funds were raised wherewith was purchased a house adjacent to the Temple. After undergoing alterations it was converted into a school. Still short of schoolhouse standards, the building nevertheless marked a great advance in the facilities it proVideả. It offered better and increased classroom space than that which had till now been available. It resulted. in less crowaing and better distribution of pupils into their appropriate grades.

To finance the school, a tuition fee was first levied. But in 1929 the membership fee of the Congregation was adjusted to include tuition. Thenceforth members had the privilege of sending their children to the school without any 
other payment than the annual dues. This was a further in the increase in enrollment which took place from 1930 onward.

Besides its weekday school Temple Beth David has, since its organization, also maintained a sunday School. Till 1930 its enrollment numbered about 150 pupils. Its curriculum provided for graduation after seven years of attendance. In 1930 the course of study was extended an additional year; to graduate, pupils now had to attend eight years. A further year of study was added for those who wished to qualify for confirmation (a religious ceremony). By keeping the old pupils in the school while new ones annually enrollea, these extensions operated to increase the Sunday School registration and it rose to over two hunared.

The staff of this department of the school was recruited at first from volunteers. Later however (in 1930) in accoraance with the, by now, familiar pattern, a system of paid teachers was inaugurated. This is the status of the school at present.

(5) Temple Emanu El: " Organized in 1924, this Congregation marked its first decade of existence by an impermanence of location. From 1924 to 1926 the Congregation met in rented quarters on Parkside Ave. necr Russel Ave. A weekday school was established with an enrollment of 25 to 30 pupils, and a staff of one teacher. Classes met in a room within the building. In 1927 the Congregation moved to new quarters on Hertel near Norwalk Ave., which it occupied 
until 1934. It continuea its school but now augmented its staff to two teachers, in response to an increase in enrollment. At the same time it inaugurated a sunday school. Registration in the weekday school in this period was approximately 120; in the sunday school there were some 200 pupils.

In 1934 the Congregation moved to its present site on Tacome and Colvin Aves., occupying what had formerly been a Baptist church. Possessing more facilities and room than ever before, the school was able to accomodate the further increase in registration, which by 1937 amounted to 175 for the weekday school and 325 for the sunday School. This increase in enroliment necessitated a further augmentation of staff, the faculty of the weekday school being increased to four teachers.

The staff of the Sunday School consisted of volunteers at first, the teachers receiving an honorarium at the end or each jear in recognition of their services. Latterly, however, the teachers of this school have been placed on a salary basis.

The Efforts of the Yidaishists

The Jewish Hational Workers' Alliance is a countrywide labor orenization with headquarters in New York and branch groups in several cities in the trited states. Its viewpoint, as a Jewish body, is nationalist (Zionist) and secularist (non-religious). It is aligned with the socialists in its 
acceptance of the theory of the class-struggle. It regards Yiddish as one of the essential media of cultural expression of the Jewish people. It also accords to Hebrew a recognized place as the historic language of the Jews. To foster its program ano seek its continuity the Alliance, through its local affiliates, maintains schools in many cities throughout the country. While the financial responsibility for the schools rests with the local bodies, the direction, supervision, curriculum, choice of texts and other pertinent matters are the concern of the central office of the organization. The schools of this body are known as "Verband Volkschulen" (National Schools of the Alliance).

(I) The Buffalo Volkschule: $(*)$

In this city, the branch of the Alliance made its first of three attempts to launch a school in 1920. Housed in its club rooms on Jefferson Ave. near Villiam St., the school conducted classes on Sunday mornings and Monday through Thursday after public school hours. There were enrolled about 50 pupils who were divided into three groups each meeting one hour daily. The faculty consisted of one teacher. The language of instruction was Yiddish, and Yiddish and Hebrew literature were taught. The school was maintained through income from tuition fees and the various efforts of the local membership of the Alliance to raise funds.

In this first attempt, the school endured only for a brief period. It closed after but one year. A lack of funds and the absence of proper and adequate facilities were the chief reasons which speeded its closing: 
But in 1925 the school resumed its existence. This time its life-span was longer; the school had a continuous existence till 1930. In its second phase it began by being housed at the Jewish Community Center. The school grew, its enrollment at the peak being some 200 pupils (of whom the majority were girls).

While the school was popular with its devotees, there were elements within the Jewish community which felt that its program was raaical and (ergo) anti-religious. They therefore protested against the use of the Jewish Community Center as a school by the Alliance. A committee of rabbis and laymen investigated the school and exonerated it of the charge that it was anti-religious. Nevertheless it was found advisable that the school should seek its own quarters. The organization purchased a building on Jefferson Ave. near Peckham St. where the school continued till it closed down in 1930.

During this period the school carried on the same program as in the year of its previous existence. The increased registration made it necessary to engage two full time teachers, who were supplemented by a part-time teacher when needed.

Eventually, however, the school had to close once again. Circumstances combined to curtail the registration: Jews were leaving the William st. area, and the Talmud Torah, which had become a ward of the Federation, offered 
schooling tuition-free, thereby arrawing away a considerable percentage of pupils from the Alliance school. It was compelled to discontinue.

One more attempt was made to revive the school in a new location. In 1932 it reopened in the Hamlin Park district in a builaing at Jefferson Ave. and Ferry St. Its registration numbered fifty pupils and it had one teacher. But the effort was foredoomed. The school existed only one year. A whole train of circumstances brought on its final end. The depression which aggravated the usual financial aifficulties of the school; the opening of a school by the Temple in the neighborhood; but chiefly, the halt of immigration which diminished the number of Yiddish-speaking Jews in this country: all these factors militated against the further existence of the school.

But while it lasted, the school won the respect of all, even of those who opposed it. Its pupils were imbued with enthusiasm. The parents held it to be their cultural center. And finally, the teachers were men of good intellectual and educational caliber, who made up by their zeal for the in- . adequacies under which they worked. In short, the school, to quote the words of Louis Hurwich in his Survey of Jewish Education in Buffalo (see next chapter); "can serve as an example of enthusiasm, devotion, and reciprocal love and respect between teachers and students." 
There remains but one further factor to consider in rounding out the picture of Jewish education in Buffalo the Bureau of Jewish Education. To the story of its inception, progress and present status, the next chapter will be devoted. 
NOTES

(*) Information concerning schools not possessing written records, or possessing them in part only, was obtained from individuals closely associated with their respective schools from their inception. Such information throughout this chapter is indicated by an asterisk $\left({ }^{*}\right)$. 1. Tractate "Shevuot" (Oaths), Babylonian Talmud, $39 a$. 2. Buffalo Jewish Review, vol. XIII, no. 1.

3. Yearbook of Federated Jewish Charities, 1910.

4. Yearbook of Federated Jewish Charities, 1910.

5. For events leading to the establishment of this annual celebration see Books of Maccabees I and II.

6. For the origin of this annual celebration see the Book of Esther.

7. The minutes of the Buffalo Hebrew School of 0ct. 4, 1916 place the registration at 191, and those of June 18, 1918 state the registration to be 180 .

8. Minutes of Buffalo Hebrew School, June 26, 1912 and June 28, 1916.

9. The various methods of financing here touched upon are mentioned repeatedly throughout the minutes. Tuition fees, membership dues ano the annual bazaar have been discontinued since affiliation with Federation. of the older sources of income only the sale of "matzo" and "shechita" (ritual slaughter) money remain. 10. Thus see minutes of B. H. S. of Feb. 3, 1909, June 2, 
1909, and May 18, 1910.

11. On the appointment of a Boara of Education from the membership of the Board of Directors, and on the scope and powers of the former see minutes of B. H. S. of Feb. 3, 1909 and Mar. 21, 1909.

12. Adopted Aus. 12, 1914.

13. Minutes of B. H. S. of Mar. 28, 1909. Also outline of course of study in Declaration of Principles. See note 12.

14. Minutes of B. H. S., May 1, 1921.

15. Ninutes of B. H. S., Dec. 31, 1923.

16. Minutes of B. H. S., Nov. 10, 1924.

17. There is a reference to this sunday school in the Buffalo Express, June 13, 1909, and in the minutes of the B. H. S. of Dec. 16, 1908.

18. Minutes of B. H. S., May 3,1916, May 24, 1916.

19. Minutes of the B. H. S., Sept. 30, 1920.

20. Temple Beth El Monthly Bulletin, no. I, June 1911.

21. From a brief historical synopsas of Temple Beth El, included in the souvenir program of the 9lst Anniversary Ball of the Temple, 1938.

22. Minutes of the School Committee of Temple Beth El, Dec. 8, 1935.

23. Minutes of the School Committee of Temple Beth Zion, Apr. 21, 1907.

24. Report of the School Committee of Temple Beth Zion, Feb. 2, 1910. 
25. Minutes of the School Cornittee of Temple Beth Zion, Feb. 4, 1910.

26. Minutes of the School Committee of Temple Beth Zion, May 27, 1915.

27. Minutes of the School Committee, Temple Beth Zion, Feb. 18, 1916 .

28. Minutes of School Committee, Temple Beth Zion, Nov.

5, 1923. How long this course continued in existence

is not indicated.

29. Minutes of School Committee, Temple Beth Zion, Mar. $9,1923$.

30. Minutes of School Committee, Temple Beth Zion, Nov. 13,1925 .

31. Minutes of School Committee, Temple Beth Zion, June 2, 1929 .

32. The first suggestion for such weekday classes occurs in the minutes of the School Committee of Temple Beth Zion, Sept. 17, 1935.

33. Minutes of School Committee, Temple Beth Zion, Mar. 11, 1934.

34. Buffalo Times, Feb. 21, 1931.

35. Buffalo Express, Nov. 24, 1924. 


\section{CHAPTIR SIX}

THE ERA OF THE BUREAU OF JEWISH EDUCATION

In establishing a central bureau for Jewish education, Buffalo was by no means a pioneer. At least twelve cities had preceded it in creating such an organization. Indeed the "beginnings of community-wide organization in the field of Jewish education in the United States are commonly associated with the establishment of the Bureau of Jewish Education in New York City in 1910."

The practical basis of all central communal agencies is - rationalization. In coordinating their activities, whether philanthropic or educational, communities are usually "motivated by a desire to eliminate duplication and friction, to introduce some balance between demand and supply, to raise standards of performance, and to provide for orderly growth in facilities and program." ${ }^{(2)}$ In short, it is an endeavor to reach a given height of achievement with an economy of outlay and effort. The degree of success in attaining the desired goal in any specific community is affected, among other things, "by local traditions and peculiarities, by group relations, and by the quality of local leadership."

But in the field of Jewish education the problem of coordination "presents a number of special problems. There is considerable divergence of opinion in the Jewish community regarding the objectives and aims of Jewish education, di- 
vergencies due to differing religious and social philosophies, to basic differences concerning the relation of the Jew to the American scene and to cultural ties with central and eastern Europe and with Palestine. The problem is made still more difficult by the several school systems, which developed in the United States and by differences in emphasis on the cultural values which they are endeavoring to nurture and preserve..... Another factor, complicating further the problem of coordination, is the congregational form of organization of Jewish religious interests, the interests most concerned with the preservation of the Jewish group as a religious entity. As developed in the United States, Jewish religious organizations direct their attention primarily to the needs of their membership.... These conditions, typical of most American communities, have provided the background for communal efforts at raising standards and coordination." (4)

With these general reflections to be borne in mind, we can address ourselves to the origin of the Bureau of Jewish Education in Buffalo.

(1) Herman Wile and His Associates: To Herman Wile is usually ascribed the paternity of the Bureau. He was "the father and inspiration of the idea." (5) Beth Zion, its president for many years (he still is its president today), he interested himself in the question of Jewish education in Buffalo. It had been borne in upon him 
and some of his associates in Temple Beth Zion - particularly Sol Levy and Jacob Tick - that there must be many Jewish children in Buffalo who were not receiving a Jewish education. Not content with general impressions, Wile decided to take steps to secure specific information. With his associates, he planned a comprehensive house-tohouse canvass, to ascertain the number, density and distribution of the Jews of Buffalo, and to learn how many chilaren of school age were receiving no Jewish education. With this information once in hand, it was felt that the problem of providing Jewish educational facilities to those lacking it could be more effectively handed. (6) This census was launched in the Fall of 1928. It was quite thoroughgoing.

(2) The Survey of Jewish Education by Louis Hurwich: Meantime, it appears that there had been formed a Citizens' Committee of Buffalo Jewry which decided to sponsor a ganeral survey of various aspects of Jewish communal life in Buffalo. (7) The surveys were conducted by the Bureau of Jewish Social Research of New York City. The field of Jewish education was surveyed by Louis Hurwich, Director of the Bureau of Jewish Education of Boston.

In conducting the survey, Hurwich made use of the findings of the census of wile and his associates. He found that there were about 20,000 Jews in the city; of these 4, 000 were children between the ages of 5 and 14 . of this number, $2,097(52.4 \%)$ were receiving some sort of 
of Jewish education. These in turn were divided as follows: I, $114(53.1 \%)$ were boys and 983 (46.9\%) were girls. survey considered the type and qualities avilable for Jewish education; the calibre of the teaching personnel; and financial problems.

After a detailed analytical study of all the then existent schools, the survey made the following principal recommendations: (1) That a Bureau of Jewish Education be organized consisting of representatives of all agencies interested in Jewish education. (2) The Bureau should completely support all community schools; the Congregational schools should continue to be financed by their respective congregations. All schools should accept the supervision of the Bureau in matters directly educational. (3) "That the Jewish Federation for Social Service accept the responsibility for financing the requirements of the Bureau."

(3) The Materialization of the Bureau: The idea of establishing a Bureau in Buffalo was, by now, therefore, no novelty. Even as Herman Wile laid plans for his census, he alreaajy contemplated a Bureau whose functions it should be: (I) to spread Jewish knowledge through education, having regard for the religious convictions and traditional beliefs of various groups; (2) to establish schools where needed throughout the city; (3) to procure able and efficient teachers; $(4)$ to act as a financial agency; (5) to coordinate educational activities; (6) to be a propaganda agency 
for Jewish education;

(7) and to instil within the community, and within its youth in particular, through education, an intelligent and sympathetic understanding of Jewish religion, culture and tradition. (12)

The recommenation of $\mathrm{Nr}$. Hurwich that a Bureau be established, thus fell upon receptive ears. And when the Bureau was actually launched upon its career in the Fall of 1929, Herman Wile became its first president.

the same time it was decided that the Bureau should be an affiliate of Federation, which was to provide for its maintenance by an annual allotment of funds.

(4) The Bureau and the Buffalo Hebrew School (Talmud Torah): Inasmuch as the Talmud Torah was already receiving its yearly budgetary allotment from Federation, it was decided from the outset that it should become a direct ward of the Bureau. The aforementioned allotment was thenceforth turned over to, and absorbed into that of the Bureau. It was further provided that the director of the Bureau was to be the educational supervisor of the Talmua Torah.

Meantime the necessary steps to procure a director were taken, and in March $1930 \mathrm{Mr}$. (later, Dr.) Ben Edidin was engaged to fill the post. (15) of its existence the Bureau's affices were located in the building of the Talmud Torah.

For several years, this school and its semi-dependent, the Fillmore Ave. school (Ahavat Achim), were the only ones 
over which the Bureau exercised direct control. The existent Congregational schools would not - and do not even now tolerate any supervision by the Bureau over them. Regardless of this, however, the Bureau made available to all schools its facilities for advice, texts, materials and the like.

(5) Efforts to Widen the Scope of the Bureau's Activi-

ties: A conception of the attempts of the Bureau to widen the sphere of its activities within the community from the second year of its existence can be gained from a perusal of the plans for that year submitted by the director. They include (I) work taward an increased enrollment in the schools (but especially in the Talmud Torah); (2) efforts to improve instruction, texts, materials and methods; training of Sunday School teachers through the establishment of classes for that purpose, which shall, however, also be made available to adults generally; (4) the establishment of clubs and classes for adolescents; (5) the Junior Review, a juvenile department in the Buffalo Jewish Review, Buffalo's Anglo-Jewish weekly paper.

(6) Tarbut (Culture) College: Indeed, it was the. third item in these plans which adumbrated one of the Bureau's more worthwhile efforts, i. e., that of Tarbut College. It was to be a school for adults, meeting one evening a week, at some centrally situated location. Apart from courses in principles and methods of teaching, designed 
to help those who taught or wanted to teach in the sunday Schools, there were to be content courses in Jewish history and contemporary Jewish life and problems. The locale of the classes was to be the Grosvenor Library ( 383 Franklin Ave.) which generously offered its facilities; and Wednesday evening was to be "Tarbut" night. The school was initiated in the Fall of 1930 , and was to be conducted from November through April. (17) and day were changed. Classes were held on Monday instead of Wednesday evenings, and the new location was Temple Beth Zion. This arrangement still prevails.

(7) Talmud Torah and Bureau Adjust Their Relations: One of the problems in adjustment which the Bureau was obliged to face from the outset was that of its relations to the Talmud Torah. Although this latter is an affiliate of the Bureau it is nevertheless an autonomous institution, governed by its own rules, controlled by its own board of directors and very jealous of its independence. Only time and experience would work out a "modus vivendi" permitting each organization to work separately in its own special sphere, and together where the situation called for joint effort. Meantime the director, whose duties required him to act as supervisor of the Talmud Torah, was in an anomalous position.

One of the first issues to arise was that of orthodoxy. This is a delicate problem and requires cautious handing. 
The Talmud Torah is committed to an Orthodox approach on all matters pertaining to Jewish life. The Bureau itself is presumably not confined to any specific outlook. It is supposed to be - and indeed strives to be - strictly neutral on all such matters.

Nevertheless the problem arose. At a meeting of the board of the Bureau, not long after the first director, Edidin, assumed his duties, there appeared the president of the Talmud Torah. He submitted that it was one of the functions of the Bureau to create goodwill. Yet adverse comment was circulating to the effect that the Talmud Torah was not being conducted along strictly Orthodox lines. (18) ter was then smoothed over, but the problem recrudesced time and again. Eventually assurances had to be given the Talmud Toreh that nothing would be done to jeopardize the Orthodoxy which is its mainspring.

Another source of friction lay in the the of the appointment, supervision and dismissal of flaculty members of the Talmud Torah. Whose function was it to engage a teacher; to dismiss a teacher; or to discipline him? Was it to be the function of the Bureau acting through its director? Or was it the province of the Board of Directors of the Talmud Torah? (20)

To reach a solution satisfactory to both sides, covering all issues and envisaging all likely contingencies, a Joint Committee, representing the Bureau and Talmud Torah, was set up. This committee worked out a Relationship Agree- 
ment which was adopted by both sides on oct. 14, 1936. It included a detailed definition of the supervisory functions of the Bureau, acting through its director. It embraced such matters as (I) classroom visitation; (2) organization of classes; (3) submission of teachers' reports; (4) initiation of matters of policy; (5) contact of the Bureau with the Board of the Talmud Torah. Arrangements were also made as to school personnel, relating to the engagment, retention and aismissal of any member of the staff. Lastly, the manner in which the allotment of the annual budget of the Talmud Torah was to be made, was likewise arranged.

The general spirit underlying the agreement was one of mutual respect and goodwill; and the harmonizing device employed was that of assigning specific tasks and responsibilities to each side. The arrangement was to operate annually, from September 1, of each year and could not be cancelled by either party except by notice submitted on or before July 31 of any calendar year. This agreement is still in force.

Since the Talmud Torah was at first the only large school under control of the Bureau, the director could give to it a large share of his attention. Some of the benefits accruing from this, were improvements in curriculum planning, modernization in plant, classroom methods and general (not religious) outlook; and an increase in extra-curricular activities. 
In 1935 a modification in the supervisory duties of the director occurred, when a member, selected from the faculty of the Talmud Torah, was appointed principal of the school. Although the director theoretically still retained his supervisory powers, he tended, in practice, more and more to relegate immediate supervision to the principal.

At all events, in spite of the aforementioned benefits conferred upon it by the Bureau, the Talmud Torah, in its present location, is a waning institution. Its registration has been in steady annual decline since 1930, chiefly because of the shifting of the Jewish population from the William St. area to other neighborhoods. What disposition should and will uItimately be made of it as regards its building, staff and thase children who remainin the vicinity and for whose Jewish education the community must be responsible - all these are problems which the Boarảs of both the Bureau and the Talmud Torah together must, within the near future, ultimately solve.

(8) The Scope of the Bureau's Functions: From time to time the Bureau would set forth the various functions which it does or should perform. This was done through the medium of definition, resolution, annual reports, or special study. In the Fall of 1932 the director, Mr. Edidin, outlined the functions of the Bureau under six heads. (22) ter, a series of six resolutions, expounding the purposes to 
which the Bureau is dedicated, was drawn up. And at the annual meeting in January 1937, Paul Veret, who had succeeded Edidin in 1935, as the Bureau's director, presented a report in which he indicated its spheres of activity and accomplishment. (24)

Except for minor details and differences in wording, a sameness of theme runs through all these statements. All awell on the neea. to increase enrollment in the schools, and improve curriculum and methods of teaching; the desirability to coordinate Jewish educational effort in the city; the necessity for granting financial aid in some form to the smaller schools; and the need to establish such educational and cultural activities as no other agency in the city is prepared wholeheartedly to create and maintain.

In consonance with this last mentioned need, the Bureau has, at various times, sponsored a number of undertakings which it once classified under two heads: Extension Activities and Coordinating Activities. The degree of consistency and continuity with which it hes maintained any of these activities has depended on their popularity, the availability of funds and the initiative of the director.

Among the extension activities which have for a time been conducted by the Bureau but have since fallen casualties from a lack of funas or other causes, are two highly worthwhile cultural and educational enterprizes: the Jewish Choral Society and the Junfor Review. The first 
is an organization which, by dint of its effort, sincerity and the quality of its performances as a vehicle for Jewish musical expression, has been able to maintain itself despite the fact that it has been deprived of its annual subsidy by the Bureau. The second refers to the regular appearance in the Anglo-Jewish weekly, the Buffalo Jewish Review, of a number of columns of reading matter, specifically prepared for juvenile readers. Its discontinuance is probably due to reasons other than a lack of funds. Among its coordinating activities are the Bureau's reference library - which will grow in value as it grows in volume; its publication of educational material; and its service as a medium for the dispensation of general Jewish information to schools, clubs and the general public. (25)

(9) Attempts at Re-orgenization: In January 1938, PauI Veret resigned as director of the Bureau. A new director was not appointed till the summer of that year. During the interregnum, the affairs of the Bureau were carriea on by an administrative directorate of three. The triumvirate included Dr. Selig. Adler (a teacher of history in the Buffalo High School system), Reverend Harry J. Brevis (gacational Director of the Young. Mends and Young Women's Hebrew Association) and Dr. Uriah Z. Engelman (who later became the Director of the Bureau and still holds that post. A new plan was elaborated to "decentralize" the Bureau "by placing authority on the respective organizations connected 
With it." To that end an Educational Councll consisting "of the Administrative Committee; Chairmaen of school Boards; Educational Directors; and Laymen" was to be established. "From this Council" were to "be appointed committees to deal directly with the various problems that arise and after the sald committees have met and come to decisions they will submit their findings and suggestions to the Administrative Committee who will in turn take them up wi th the Executive Board." (26)

This arrangement was never fully implemented. In August of that year Dr. Engelman was appointed Director of the Bureau, which continued to operate as before: $i$. e., through an executive board chosen from a board of directors not at all as eclectic in its composition as had been proposed. All matters of policy are framed by this board and are, in turn, given practical effect by the executive director.

(10) Expansion of Activities: The year 1936 marked the beginning of more expanded activities for the Bureau. Until then its outright sphere of activity was limited to two schools: the Talmud Torah and the Ahavat Achim school on Fillmore Ave. Thenceforth it took an active part in establishing schools within the smaller congregations, or in aiding such schools as: were already established.

The method on which the Bureau based its financial aid to these schools was that of scholarship grants; i. e., for every pupil on the rolls of such schools, whose tuition was not otherwise paid, the Bureau was to make a monthly 
grant of two dollars, for ten months of the year. The Bureau did not undertake to assume thereby the ultimate financial responsibility for the maintenance of these schools; this rested with each of the individual congregations concerned.

The schools reached by this arrangement are (I) the. Ahavet Achim school at 833 Fillmore Ave., which was reorganizea in 1936 to conform to this arrangement; (27) Anshe Zedek (Men of Righteousness) at 85 Saranac Ave. in the Fertel section; (28) (3) Beth Abraham (House of Abraham) (3) Beth Abraham (House of Abraham)
(29) at 1045 Fimwood Ave. in the Elmwood-Richmond district; and (4) Ohel Jacob (Tent of Jacob) at 493 East Ferry st.
in the Hamlin Park area.

(11) The Workmen's Circle School: In addition to these Congregational schools one other school - non-Congregational - was accorded the aforementioned form of assistance. In 1937 a school of the Yiddishist type had been started by the Workmen's Circle (3I) Jefferson Ave. (Hamlin Park). In the second year of its existence it applied to the Bureau for a subvention.

In view of the fact that the school's sponsors were held suspect of radical and anti-religious leanings, a committee from the Workmen's Circle appeared before the executive board of the Bureau and stated its position in the following terms:

The Workmen's Circle is neither a socialist pr commu- 
nist organization but a fraternal order. It "is interested in maintaining a Jewish school. The curriculum of the school includes Jewish language (Yiddish], history, literature and also Bible in Yiddish. They accept children wishing to enroll, whether they [the children] are able to pay or not. They have a grant of three hundred dollars from the Central organization in New York and the rest of the money they raise themselves 1ocally." A committee of three was appointed to investigate the application.

Iventually, after the school had agreed to meet the terms of the Bureau, 1. e., to add Hebrew instruction to Its curriculum and to give aded stress to the teaching or Jerish holiabyg, it was put on an equal footing with those schools already receiving aid from the Dureau. It was given a monthly grant for tach pupil unable to paj a tultion fee.

(12) The High Schools of the Bureau: Among the problems with which the Bureau has endeavored to cope is the vexing question of prolonging the schooling of those adolescent pupils who have exhausted the possibilities of their weekday schools. It first sought to tackle the issue by means of establishing high schools, located in the separate schools, and taking care of the pupils of these schools. The Bureau paid the salaries of the teachers engaged in this work.

The effort was begun in 1936 and in February of that year the Bureau reported four units in operation, one in 
each of the Conservative temples and one at the Talmud Torah. The combined registration was put at "about 50 students." (34) The question of centralizing the high schools by having one meeting place for all, was occasionally discussed; but the practicability of such a step was mooted. The undertaking lasted only two years; in 1937 the high schools were discontinued.

However, in the Fall of 1939, the project was resumed. This: time a centralized high school was established, with pupils from the various schools meeting at the building of the Young Men's Hebrew Association on Iinwood Ave. Classes meet two hours a day in the late afternoon two days a week. It is too soon to be able to say whether this effort will prove more enduring than its predecessor.

(13) The Bureau and the Community Religious School:

In June 1936 the Bureau took over the direction of the Community Religious school. (36) the Sisterhood of Zion extended to the Bureau the right to exercise complete supervision. The Sisterhood, however, was still to remain affiliated with the school by means of its Advisory Board which was to cooperate with the Board of the Bureau. (37)

vided by the Bureau. This arrangement is presently in force. The school itself is directed by a principal, who, however, submits all his reports to the Bureau. The principal also advises with the Bureau's director on all matters 
relating to policy, curriculum, expenditure and other pertinent details.

Although situated in an area which Jews are steadily leaving, the school yet contrives to hold its ground. This may be accounted for by (I) the loyalty of former students who, in many instances, now: send their own children to the school even from a considerable distance; (2) the added emphasis placed upon the work done by the higher classes and the establishment of a two-year post-graduate course which, together, tend to retain the older pupils in the school over a longer period.

Still it would be deluding to believe that the school has come off entirely unscathed. It is witnessing a gradual drop in registration which loyalty and resourcefulness can retard but not stop.

(14) An Estimate of the Bureau's Accomplishments in General Terms: In June 1939 the Bureau celebrated ten years of its existence. In that interval it has gradually expanded the terrain in which it operates. But thus far its positive achievements can be stated by and large in numerical terms only. It expends so many dollars a year; it provides education for so many chilaren; it operates in whole or in part so meny schools; it reaches out its contacts, in one way or another, to so many organizations and so many individuals of the community. 
After ten years the Bureau has not yet achieved one of the cardinal aims for which it was called into being; there is still no real unified system of all the schools, not even among the schools that are affiliated with the Bureau. As for the temple schools, they hold themselves as aloof from the Bureau today as in its first days. Theoretically they wish it well, but in practice they maintain their separateness sturaily.

In general too much attention is given to how many pupils are in the school but not enough scrutiny of what is done with them there and what they ultimately accomplish.

To be sure, the Bureau is: confronted by handicaps which tend to stultify its efforts. Its budget is subjected, from time to time, to cuts; it exists in constant dread of ever impending reductions. Its hands are tied by the fact that the schools it does supervise, are also subject to a measure of control by the separate school boardsa situation which sometimes creates friction and leads to misunderstanding and conflict. It is also under the obligation to be rigorously impartial; it must be neutral entirely free of the suspicion of having leanings to any particular group in the community.

All these factors in themselves tend to limit the full and salutary operation of the Bureau. Yet another conditioning influence is that of the executive director; 
his personality, ability, ingenuity, and sagacity - to the extent that he possesses these qualities - are determinants of considerable magnitude.

However, ten years is a brief span of time in which to measure the extent and quality of the influence and efficacy of an institution such as the Bureau. Perhaps more time must be allowed to elapse before the Bureau's achievements are passed under the rod for definitive juagment. 
NOTES

1. Community Organization for Jewish Education, Council of Jewish Federations and Welfare Funds, New York, oct. 1939, p. I and footnote.

2. Ibid, p. 2.

3. Ibia., p. 2 .

4. Ibid.,pp. 2 and 3.

5. Buffalo Jewish Review, Aug. 31, 1928.

6. Ibid., Aug. 24, 1928.

7. Ibid., Mar. 11, 1929.

8. Survey of Jewish Education in the Buffalo Schools by Louis Hurwich (on Ille at the Bureau of: Jewish Education, Buffalo, N. Y.), 1929.

9. For a digest of the Survey see Jewish Education, vol. II, no. 2, June 1930, pp. 85-87.

10. Buffalo Jewish Review, July 13, 1928.

11. Ibid., July 20, 1928.

12. Ibia., sept. 7, 1928.

13. Ibid., Oct. 11, 1929.

14. Minutes of Buffalo Hebrew School, July 31, 1930.

15. Minutes of the Bureau of Jewish Education, Mar. 31, 1930.

16. Minutes of the Bureau, Sept. 18, 1930.

17. Minutes of the Bureau, Oct. 20, 1930.

18. Minutes of the Bureau, Dec. 18, 1930. 
19. Minutes of the Buffalo Hebrew School, Sept. 17, 1935. 20. Minutes of Buffalo Hebrew School, Oct. 2, 1933, and Dec. 6, 1934.

21. A copy of the arrangement is included intthe minutes of the Bureau.

22. Minutes of the Bureau, Oct. 11, 1932.

23. Minutes of Burequ, Sept. 5, 1935.

24. Minutes of, Bureau, Jan. 5, 1937.

25. Minutes of Bureau, April 2, 1936.

26. Minutes of Bureau, Jan. 24, and Jan. 31, 1938.

27. Minutes of Bureau, Jan. 9, 1936.

28. Minutes of Bureau, June 11, 1936.

29. Minutes of Bureau, Oct. 26, 1936.

30. Minutes of Bureau, Aug. 2A, 1938.

31. For the underlying philosophy and outlook of the Work-

men's Circle and its schools see above, Chap. I, pp.

18-19 and $\mathrm{p} .23$.

32. Minutes of Bureau, oct. 11, 1938.

33. This information was given by the Director of the

Bureau, Dr. Engelman.

34. Minutes of Bureau, Feb. 24, 1936.

35. Minutes of Bureau, Apr. 2, 1936.

36. See Chap. V, pp. 81-87.

37. Minutes of Bureau, June 11, 1936. 


\section{$-132-$ \\ CHAPTER SEVEN \\ TRENDS AND TENDENCIES}

Almost a century has passed, ninety-three years to be exact, since formal Jewish education was launched in Buffa10. It is here in point to attempt to survey comprehensively what has been told in the foregoing chapters in detail.

(1) Collateral Agencies: It must be borne in mind that only the progress of formal Jewish education has been considered. For in addition to the schools, various agencies exist, conducting activities many of which have distinctly educational implications and values. But these are merely incidental and the institutions which foster such activities are primarily motivated by other concerns. This is not to say that those who direct these activities are not fully aware of their educational significance. On the contrary, they fully realize, welcome and, indeed, exploit their educational potentialities to the full.

Nevertheless, because of the informal character of their programs, and because they are not schools either in name or fact, these institutions have not been considered here. Instances of such collateral Jewish educational agencies abound in Buffalo. To mention only a few, there are the Jewish Community Center (in the William St. district), the Young Men's and Young Women's Hebrew Association (in the Richmond-FImwood district, and within easy reach of the Hamlin Park district as well), the various Zionist adult and youth groups and a host of variegated 
social and cultural clubs, utilizing the community halls of the temples and synagogues as their places of meeting.

(2) Recapitulation: What developments have ninety-three years of formal Jewish educational effort witnessed in Buffalo? Within these years have arisen almost all of the various types of Jewish school: the Congregational weekday and Sunday Schools; the "cheder"; communal weekday and Sunday Schools; two types of Yiddishist school; and a Bureau of Jewish Education one of whose ultimate aims it is to achieve the unification of all the Jewish schools within the city into one system.

The schools, in turn, each reflect the varied religious, secular and economic standpoint of their respective sponsors; being Reform, Orthodox or Conservative; nationalist (Zionist) or non-nationalist (non-Zionist); or representing the outlook of the labor group. It is almost needless to add that these alignments are not necessarily rigid; indeed, overlapping is quite common. Thus an Orthodox Jew may also be a Zionist; a member of one of the labor groups may also be an indefatigable worker in a synagogue.

(3) Handicaps: Jewish education operates, even at best, under certain shortcomings. Difficulties simply inhere in its path from the very nature of the case. It requires the expenditure of large sums of money which, in one form or other, are voluntarily contributed. Its immediate concern is the dissemination of a culture which must, under the circumstances, be a subsidiary one. In 
Its weekalay schools it must deal with the child after he has already attended the public school for a full day. There are no laws to compel attendance. The cooperation by the individuals who constitute the community rests on no other force than that of good will and the moral impulsion to be obligated. This is true alike in the matter of finances and in the willingness of parents and children to submit to the necessary discipline required for the efficient operation of a school.

A further difficulty is encountered in the absence of a definitely responsible attitude to the teacher. For the teacher in the Jewish school there are no laws to insure his security of tenure, reasonable increases in remuneration at regular intervals, a specific maximum as a salary goal, or pension provisions against old age. He is subject to the whims and fancies which may at any time prevail within the community. Should the community feel the need for economy, then is he among the first victims. Naturally such a condition cannot have a beneficient effect on Jewish education as a whole.

(4) Progress: Nevertheless, the passing years have shown progress in many directions. There has been a steady increase in the absolute number of individuals receiving a Jewish education. (I) still being made - in the physical facilities of the schools. Education has become more widespread, being now 
available to adolescents and adults, as well as children. The curriculum is undergoing in all schools a gradual process of refinement, whose aim it is to make Jewish education more adaptable to the American milieu. Finally, it is a far cry from the factotum who taught, what time he was occupied with numerous aditional duties, in the first days of Congregation Beth EI, to the modern, specialized and (increasingly) American born, college-trained teacher.

To the Jewish schools must also be given the credit for an accomplishment which is taken for granted but whose importance is not lessened one whit thereby. It is a fact that since their inception, the Jewish schools have kept successive generations of Jews in touch with their religious faith, their folkways, their culture and their brother Jews throughout the Diaspora.

(5) Americanizing Influences: It is but natural that Jewish schools, conducted among normal American surroundings, such as Buffalo presents, should feel their environmental influences. This is discernible in two directions: externally and internally. The former is instanced by the constant desire and effort on the part of the Jewish schools to improve their physical facilities; their endeavor to secure American-born or Americanized individuals as teachers; their increasing attention to curriculum planning; and their efforts to achieve efficiency in operation along 
lines characteristic or American schools. Thus America, through its schools, serves as a standard and a goal.

The second line of influence is more subtle and permeates beneath the surface of Jewish life. It is evidenced by its effect on ideological aspects in the curriculum of the Jewish school. It consists in the emphasis laid, where the subject permits it, on the elements and ideals which are common to Jewish and American life: love of freedom; respect for the rights of the individual; and a firm belief in and adherence to the democratic way of Iife. It is further discernible in the stress laid on the observance of American patriotic holidays; in the fact that a course in the history of the Jevs in the United States is given in practically every Jewish school; in taking the opportunity whenever it arises, whether in class or at school or public assemblies, to indicate the share of the Jews in the making of America; and in the culling out, for classroom use, of the best of American expression by its leading statesmen: and thinkers on the subject of the Jews.

(6) Trends and Tendencies Summarized: Having in mind all that has been portrayed, it is here in point to summarize the trends and tendencies which are indicated by Jewish educational effort in Buffalo:

1. To increasingly modernize Jewish education, by 
improvement of the physical facilities of the schools, by adapting the curriculum to the needs of American life, and by engaging bettertrained, American-born or Americanized teachers.

2. To stress the importance of religious education; it is not mere financial urgency which impelled the Workmen's Circle to accede to the stipulation of the Bureau that it give added stress to the teaching of Jewish customs and holidays. There is a growing sentiment among secular groups that the elimination of the religious element from their way of iife may have been somewhat extreme.

3. To make Jewish education more avaliable - especialIy to those who are without means or facilities f'or it. In Buffalo ine Dureau endeavors to perform this funation.

4. As a corollary or the last-mentioned tendency must be recorded the growing recognition that educational undertakings are a communal, no less than, a Congregational responsibility. 5. To recognize increasingly the essentiality of the place of Hebrew in Jewish education; witness the efforts of the Reform school - Temple Beth Zion - to introduce weekday classes in Hebrew. 
6. To expect a more intensive and extensive Jewish education than is provided merely through Sunday Schools. Educators and, more recently, laymen realize the inadequacy of the one-daya-week school for the transmission of a cultural heritage as oId and as extensive as the Jewish is.

7. To introduce system and whatever measure of uniformity is possible throughout the Jewish schools in the community. This is the task of the Bureau.

8. To realize that Jewish eaucation is not the exclusive province of the child, but that it is also essential for adolescents and adults. Hence the high school and Tarbut conducted by the Bureau, and the post-graduate classes instituted by the schools of the temples. 9. To plan Jewish education on the principle that it is supplementary to - and not a replacement of - American education.

10. To give recognition, through educational channels, to the common bonds of American and Jewish life.

11. To recognize that Jewish education is a means of acquiring that information and those skills Which will make Jewish life in Anerica a wholesome, positive and culturally enriching ex- 
perience.

(7) Buffalo a Typical City: This stuay has confined itself to a consideration of Jewish education as it obtains in Buffalo. But it is very probable that the picture presented is, on the whole, typical of all the Jewish communities in this country; all, at least, with a population (Jewish) of, let us say, 5, 000 or more. To be sure, each community will differ in certain details. The location, the numbers, the composition of the community as regerds the religious, social, national and economic outlook of its members, the age of the community - all these will be factors tending to create differences in some aspects. But in its broad lines: in its aims, its ideals, its achievements, its general line of development, in its reflection of the various segments which constitute the customary pattern of American Jewish life, in its problems and in its relation to the American environment and American education;-in all these respects Buffalo is probably typical of many Jewish communities in the United States.

From this aspect a study of the history of the progress of Jewish education in Buffalo presents a criterion of its nature and experience throughout the land. 
NOTES

1. The following figures represent the registration in the various schools for the current year, 1939-1940. They were obtained on request from the heads of the schools.

A. Congregational weekday schools

I. Temple Beth EI (Richmond Ave.)-- 100 pupils

2. Temple Beth Zion (Delaware Ave.)-- 40 pupils

3. Temple Beth David (Humboldt Parkway)-- 167 pupils

4. Temple Emanu EI (Colvin Ave.)-- 157 pupils

B. Weekday schools affiliated with the Bureau

1. Buffalo Hebrew School (Hickory St.)-- 178 pupils

2. Ahavat Achim School (Fillmore Ave.)-- 44 pupils

3. Anshe Zedek School (Saranac Ave.)-- 82 pupils

4. Beth Abraham School (Elmwood Ave.)-- 43 pupils

5. Ohel Jacob School (E. Ferry St.)- 60 pupils

6. Workmen's Circle School (E. Ferry St. and Jefferson Ave.)-- 62 pupils

7. Central Hebrew High School (Iinwood Ave.)- 17 pupils

C. Congregational Sunday Schools

1. Temple Beth El-D 200 pupils

2. Temple Beth Zion-- 472 pupils

3. Temple Beth Davia-- 223 pupils 
4. Temple Emanu EI-- 295 pupils

D. Sunday Schools affiliated with the Bureau

1. Jewish Community Religious School (Jefferson Ave.)- 402 pupils.

2. Anshe Zedek School-- 120 pupils

The total registration in all the weekday schools for this year was - 950; in all the Sunday Schools it was 1,712. These figures represent a decrease in weekday attendance and an increase in sunday school attendance, in comparison with the attendance in 1938 (for which see chart on p. 141a). 


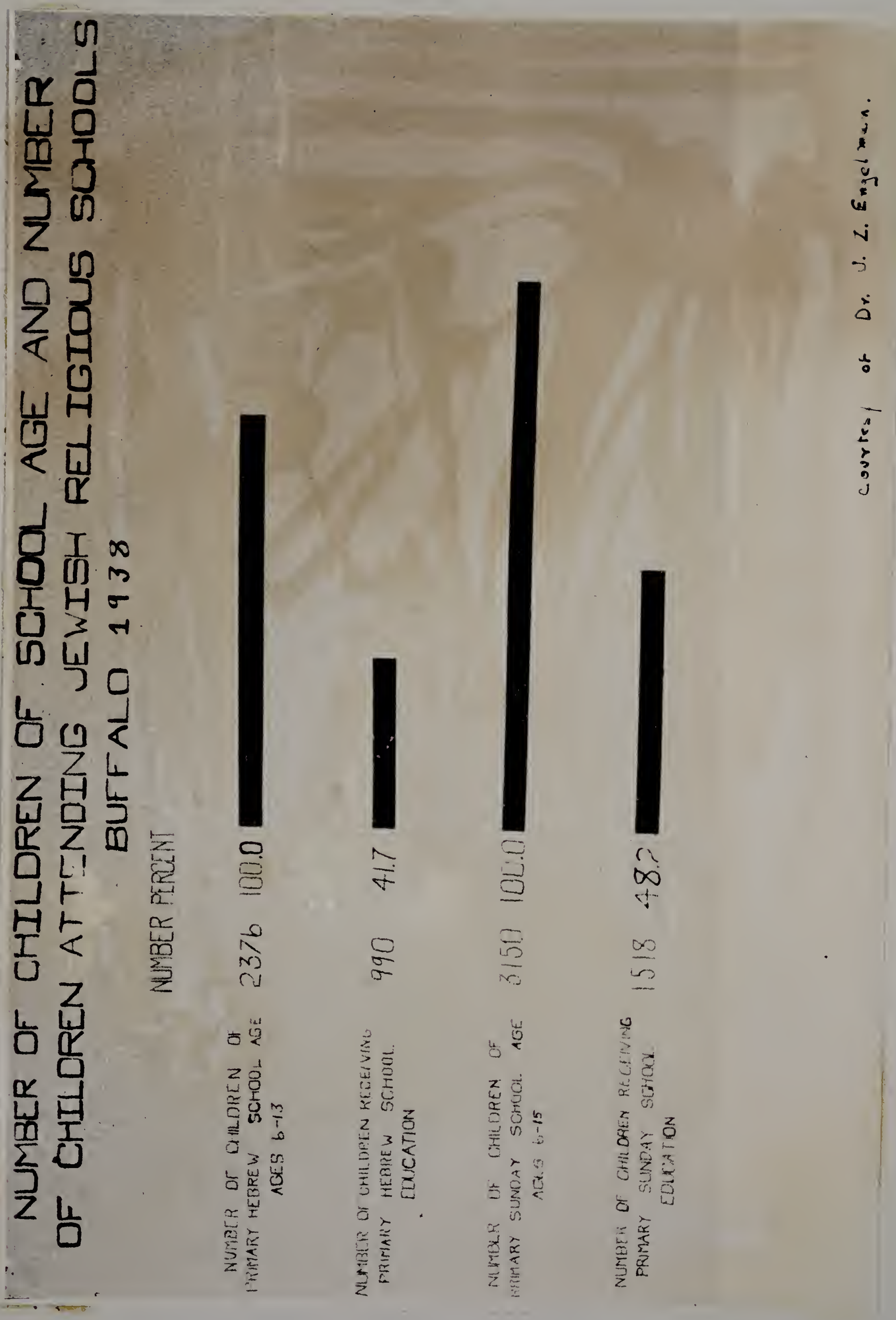


ACTINOWLEDGENENTS

In gathering information on the subject of this thesis, I was aided by the following:

Mr. Morris Diamond, one of the first teachers in the Buffalo Hebrew School, whose personal account of that school's early days was of great value; Mr. Isadore Lavenda, present principal of the Buffalo Hebrew School, from whom I got many important details and who was instrumental in obtaining for me the minute books of the Board of Directors of the school; Mirs. Rebeccah Swados, a former principal of the sunday School of the Buffalo Hebrew School, who gave me information about the Sunday School; the late Mr. Charles Polakoff, who aided me in obtaining the minute books of Temple Beth El; to Miss Julia Hannemen its secretary, who was always cooperative in furnishing me with the minute books at any time of the day; and to Mr. Samuel Luskin, a member of the faculty, who supplied me with information culled from his twenty-five years and more of service with the Beth EI school.

To Mr. Herman Wile I am indebted for permitting me to have access to all the available records - the minutes of the Temple proper and of the School Committee of Beth Zion; to its rabbi, Dr. Joseph I. Fink, and to the educational director, Mr. Samuel Rosenberg, both of whom geve me information on the contemporary state of the school; and to Miss 
Lenny Schnittman, secretary of Temple Beth Zion, who called my attention to the existence of records whenever she discovered them.

I am also grateful to $D_{r}$. Uriah Z. Engelman, executive director of the Bureau of Jewish Education of Buffalo, who permitted me to make full use of the files and minutes of the Bureau, and who gave me any information which he personally possessed whenever called on to do so.

I am also thankful to $\mathrm{Mr}$. Louis Shocket, director of the Jewish Community Center who supplied me with some data, and to Mr. Abraham Axelrod, present principal of the Jewish Community Religious School, who made available to me his personal fund of knowledge as to the origin, and progress of the school; and to Mr. Jacob Tick and Judge Samuel J. Harris, former superintendents of the school who gave me of their time and knowledge.

For information concerning the Ahavat Achim School (Fillmore Ave.) I am obliged to Mr. Shalom Yochelsom. To Mr. Joseph Sanes I am thankful for supplying me with data on Temple Beth David, and to Mr. Hyman Kahn for performing the same service in connection with Temple Emanu El. I also wish to record my thanks to Mr. Morris I. Hoffman and the late Mr. Abraham B. Wagner who provided me with the details of the Volkschule. To Mr. Ira Powsner I am indebted for the account of Mr. Diamond's Cheder. 
I must also express my thanks to Dr. Augustus. H. Shearer, Iibrarian of the Grosvenor Iibrary of Buffalo, who gave me freely of his time and knowledge and directed me to sources of information concerning the history of the city of Buffalo. In this connection the Iibrarian and staff of the Buffalo Historical Society were also very helpful.

To Dean I. O. Cummings of the School of Education of the University of Buffalo I am grateful for discussing the thesis with me and for valuable suggestions and comment.

To Dr. Israel Efros, head of the Department of Semitics of the University of Buffalo, Iam particularly inaebted for his kindness and generosity in giving me freely of his time and knowledge, and in being my guide and mentor locally.

I am especially obligated to Professor Winthrop S. Welles, head of the Department of Education of Massachusetts State College. By his encouragement and guidance and neverfalling sympathy, I was stimulated and heartened throughout every stage of the work.

Lastly, I should like to speak of my co-worker in the vineyard of Jewish education - my wife, whose zeal and cooperation cheered me onward, and who willingly performed that most arduous but highly essential task of proofreading the manuscript.

It is a pleasant duty to give thanks to so many friendly and helpful persons. I need hardly add that whatever 
merit may attach to this work is attributable, in large measure, to them. For its shortcomings, I alone am accountable.

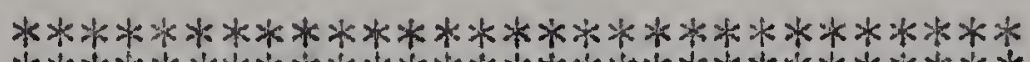

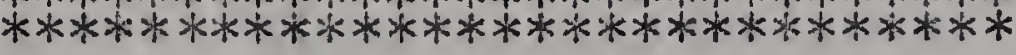

\section{ADDENDUM}

Sometime after the above acknowledgements had already been recorded, I received the charts and a map from Dr. U. Z. Engelman, Executive Director of the Bureau. The map had to be modified and adapted to the needs of this study. For permitting me to use this material, I wish to extend to $\mathrm{Dr}$. Engelman my thanks.

The photographic copies of the charts were made by Dr. William Stone (M. D.), to whom the cause of Jewish culture, in general, and Jewish education, in particular, is very dear. I am glad of the opportunity offered here to express my gratitude to him. 


\section{REVIEW OF IITERATURE}

A conception of the variety and scope of literature on Jewish education in general and on related subjects cen be gained from the bibliography of Doctoral Dissertations and Master's Theses on Jewish Education and Kindred Themes, published in Jewish Education, vol. XI, no. 3, Jan. 1940, pp. 188-195.

For material published in Jewish Education itself, from vols. I to $X$ inclusive (Jan. 1929 through Dec. 1938), see the cumulative index in Jewish Education, vol. XI, no. 1, April 1939, pp. 68-76.

Additilonal information on the literature of the subject can be gained from a perusal of the bibliographies contained in works referred to in the body of this thesis, such as, Changing Conceptions in Jewish Education by Emanuel Gamoran and Jewish Education in New York City by Alexander M. Dushkin.

For available material on Jewish education in Burfalo see the section entitled Source Material in the ensuing bibliography. There are also references to the subject scattered throughout the Buffalo Jewish Review. 


\section{BIBLIOGRAPHY}

SOURCE MATERIAI

JEWISH IITERETURE

A. General Reference

B. Democracy and Education

GENERAL LITERATURE

A. Democracy and Education

IITERATURE ON BUFFAIO

A. Americanization

B. General Background

C. Jews in Buffalo

NEWSPAPERS AND PERIODICALS

A. General

B. Jewish

PAMPHLETS

A. Jewish 


\section{BIBIIOGRAPHY}

SOURCE MATERIAI

1. F1fteenth Census of the United States: 1930, Population,

Vol. III, part 2, U. S. Govt. Printing Office, Washington, 1932.

2. Minutes of the Buffalo Hebrew School, Buffalo, N. Y.

3. Minutes of the Bureau of Jewish Education, Buffalo, N. Y. 4. Minutes of the School Committee of Temple Beth El, Buffa10, N. Y.

5. Minutes of the School Comittee of Temple Beth Zion, Buffalo, N. Y.

6. Minutes of Temple Beth El, Buffalo, N. Y.

7. Minutes of Temple Beth Zion, Buffalo, N. Y.

8. Report of the School Committee of Temple Beth Zion, Feb. 2, 1910, Buffalo, N. Y.

9. Souvenir Program of the Ninety-first Anniversary Ball of Temple Beth El, Buffalo, N. Y., 1938.

10. Survey of Jewish Education in the Buffalo Schools, by

Louis Hurwich, (on file at the Bureau of Jewish Education, Buffglo, N. Y.), 1929.

11. Temple Beth El Monthly Bulletin, no. I, June 1911.

12. Yearbook of Federated Jewish Charities, Buffalo, N. Y., 1910.

JEWISH IITERATURE

A. General Reference

1. Kaplan, Mordecai M.: Judaism as a Civilization, Macmil- 
Ian, N. Y., 1934

2. Karpf, Naurice J.: Jewish Community Organization in the United States, Bloch Publishing Co., N. Y., 1938.

3. Margolis, M. I. and Marx, Alexander: A History of the Jewish People, Jewish Fublication Society, Philadelphia, 1927.

4. Tractate "Shevuot" (Oaths), Babylonian Talmud, folio $39 a$. B. Democracy and Education

1. Berkson, Isaac B.: Theories of Americanization, Bureau of Publications, Teachers College, Columbia University, N. Y., 1920 .

2. Chipkin, Israel S.: Twenty-Five Years or Jewish Education in the United States, Jewish Education Association, N. Y., 1937.

3. Dinin, Samuel: Judaism in a Changing Civilization, Teachers College, Columbia University, N. Y., 1933.

4. Dushkin, Alexander M.: Jewish Education in New York City, Bureau of Jewish Eaucation, N. Y., 1918.

5. Gamoran, Emanuel: Changing Conceptions in Jewish Education in two books, Macmillan, N. Y., 1924.

\section{GENERAL IITERATURE}

A. Democracy and Education

1. Adams, James Truslow: The Epic of America, Little Brown. and Co., Boston, 1931. 
2. Beard, Charles Austin: The Unique Function of Eaucation in American Democracy, Educational Policies Commission, National Education Association of the United States, Washington, D. C., 1937.

3. Bourne, Randolphe: The History of a Literary Radical, B. W. Huebsch Inc., N. Y., 1920.

4. Brown, Francis J. and Roucek, Joseph Slabey, eaitors: Our Racial and National Minorities, Prentice-Hall Inc., N. Y., 1937.

5. Butler, Nicholas Murray: The Meaning of Education; (revised and enlarged edition), Scribner, I. Y., 1915. 6. Croly, Herbert: Progressive Democracy, Macmillan, N. Y., 1914.

7. Dewey, John: Democracy and Education, Macmillan, N. Y., 1916.

8. The Essential Place of Religion in Education, Monograph published by National Education Association, Ann Arbor, Mich., 1916.

9. Finney, Ross Lee: A Sociologlal Philosophy of Eaucation, Macmillan, N. Y., 1929.

10. Follett, Mary P.: Creative Experience, Longmans Green, N. Y., 1924 .

11. Kilpatrick, William Heard: Education and the Social Crisis, Liveright Inc., N. Y., 1932.

12. Lotz, Pbilip H., editor ana Crawford, I. H., co-editor: 
Studies in Religious Education, Nashville, Tenn., 1931.

13. Lynd, R. S. and H. M.: Middletown, Harcourt Brace and Co., N. Y., 1929.

\section{IITERATURE ON BUFFAIO}

A. Americanization

1. Americanization of Buffalo, pamphlet (probably) issued in 1917 or 1918 by the Civic Education Association of Erie County, N. Y.

2. Rumball, Edwin A.: Participating Americens, pamplet (probably) issued in 1917 or 1918 by the Civic Education Association of Erie County of New York.

B. General Background

1. Buffalo City Directory, published annually by J. W. Clement anà Co., Buffalo, N. Y.

2. "Buffalo in History", article by F. H. Severance, in the Christian Endeavor World, June 19, 1919.

3. Carmer, Carl: Iisten For a Lonesome Drum, Farrar and Rinehart, Inc., N. Y., 1936.

4. "The City of Buffalo", article by Frederick J. Shepard, in the New: England Nagazine, April 1893.

5. International Railway Co., Bus and Street Car Guide, Bufralo.

6. Our Country and Its People, A Descriptive Work on Erie County New York, The Boston History Co. Publishers, 1898. 
7. Severance, Frank: "A Historical Sketch of Buffalo", in the Civic Section of the Buffalo City Directory, 1920.

c. Jews in Buffalo

1. Adler, Selig: "A Study of the Early Jewish Community of Buffalo, 1835-1880", article in Buffalo Jewish Review, Oct. 14, 1932.

2. Allen, Hon. Lewis F.: "Founding of the City of Ararat on Grand Island- By Mordecai M. Noah", Publications of the Buffalo Historical Society, Vol. I, Bigelow Bros., 1879.

3. Falk, Rev. Sampson: "A History of the Israelites in Buffalo", Publications of the Buffalo Historical Society, Vol. I, Bigelow Bros., 1879.

NEWSPAPERS AND PERIODICALS

A. General

1. Buffalo Express, May 16, 1909 and Nov. 24, 1924.

2. Buffalo Times, Feb. 2I, 1931.

3. Directory of Newspapers and Periodicals, N. W. Ayer and Sons, Inc. 1939.

\section{B. Jewish}

1. Buffalo Jevish Review

2. Jewish Education, vol. II, no. 2, June 1930. PAMPHLETS

A. Jewish

1. Community Organization for Jewish Faucation, Council of 


$$
-153-
$$

Jewish Federations and Welfare Funds, N. Y., Oct. 1939.

2. Witt, Rabbi Louis: Judaism and Democracy, Jewish Tracts No. 1I, Union of American Hebrew Congregations, Cincinnati, ohio. 


\section{THE UNIVURSTTY OF BUPFALO BUFEALO, NEW YORT}

May 6,1940

Dear Professor Welles:

Mr. Klein's study of Jewish education in Burialo is a. creditable contribution. Its presentation of the sociological background is illuminating; its facts are important and. authoritative; and its general viempoint is inspired by a synthesis of liberal Anerican thought and the Hebrew quest of survival.

Faithruliy yours

Israel Efros 


\section{Approved by:}

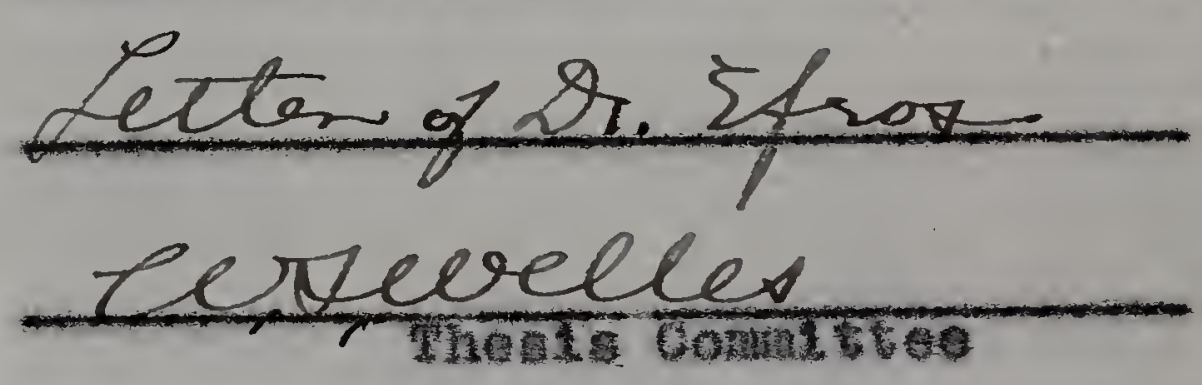

Date $222 x_{y}, 1940$ 
